\title{
BANKING ON A BAILOUT: DIRECTORS' AND OFFICERS' LIABILITY INSURANCE POLICY EXCLUSIONS IN THE CONTEXT OF THE SAVINGS AND LOAN CRISIS
}

\author{
M. MAZEN ANBARI $\dagger$
}

A record number of savings and loan associations ( $S \& L s)^{1}$ have failed in the past few years, resulting in a financial crisis that has placed a phenomenal burden on the federal budget. The S\&L debacle has spawned a great variety of litigation between federal regulators and the directors and officers (D\&COs) of failed S\&cLs, the latter widely regarded as major culprits in the crisis because of press reports detailing reckless, and sometimes outright fraudulent, management practices. Like the D\&Os of other corporations, S\&L managers frequently carry $\mathrm{D} \& \mathrm{O}$ liability insurance. ${ }^{2}$ The federal

† B.A. 1987, University of Pennsylvania; J.D. Candidate 1993, M.D. Candidate 1993, University of Pennsylvania. I would like to thank Professors Stephen A. Cozen and Jeffrey S. Lange for their comments on earlier drafts of this Comment, and Messrs. Konrad S. Alt, Eugene J. Comey, Ronald R. Glancz, Robert F. Schiff, and John $V$. Thomas for the useful information they provided. I am grateful to my fellow Law Review editors for their invaluable assistance.

${ }^{1}$ Savings and Loan Associations are depository institutions whose two main functions have been to hold checking and saving deposit accounts and to provide loans, primarily residential mortgages. S\&Ls may be chartered under either federal or state law, and they may be formally organized in either stock or mutual form. See LAWRENCE J. WHITE, THE S\&L DEBACLE 13-15 (1991). For a detailed description of the industry, see id. at 14-23; see also WALTER J. WOERHEIDE, THE SAVINGS AND LOAN INDUSTRY 3-27 (1984) (discussing the history of the Federal Home Loan Bank System). S\&Ls are distinguished from commercial banks by the dominance of residential mortgage lending in their portfolios. See Alex M. Azar II, Note, FIRREA: Controlling Savings and Loan Association Credit Risk Through Capital Standards and Asset Restrictions, 100 YALE L.J. 149, 151 (1990). The term "thrift institution" applies to S\&Ls as well as other financial institutions such as credit unions, which take deposits from, and provide consumer loans to, members of a defined group such as labor unions or college students. See id. at $150 \&$ n.3.

$2 \mathrm{D} \& \mathrm{O}$ liability insurance protects corporate D\&Os against the liabilities that they may incur for decisions they make in their corporate capacity. These liabilities may arise out of decisions regarding such things as investments, takeovers and mergers, and securities regulation matters. Under state laws, the corporation itself is permitted, and in certain instances required, to indemnify the D\&Os for some of

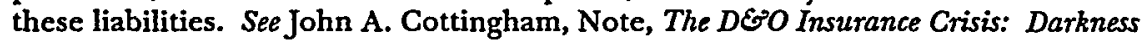
at the End of the Tunnel, 39 S.C. L. REv. 653, 676-84 (1988). Accordingly, a typical D\&O policy comes in two parts. The first part covers the D\&Os directly, and the 
government naturally attempts to recover on these policies when it sues insured S\&L executives. Federal regulators' attempts at recovery from insurance companies have been hindered, however, by exclusions found in many $\mathrm{D} \& \mathrm{O}$ policies that were introduced by insurers in the mid-1980s in anticipation of the massive $D \& O$ liabilities that would result from widespread failures of S\&Ls. Arguably, these exclusions deny coverage for suits brought by federal banking regulatory agencies. A court's interpretation of the scope and permissibility of these exclusions often decides the fate of the government's multi-million dollar suits against D\&O insurers. The exclusion litigation has been particularly contentious because the federal regulators often argue that any exclusion meant to bar their suits should be invalidated on its face on grounds of public policy. They argue that these exclusions interfere with their statutory duty, under the Financial Institutions Reform, Recovery, and Enforcement Act (FIRREA), ${ }^{3}$ to resolve the failed S\&Ls. This Comment will comprehensively review both the substance of this litigation and the policy issues lurking beneath it.

Specifically, Part I of this Comment will address the dimensions of the S\&L crisis and the D\&O liability litigation that followed. The two policy exclusions that have slowed federal regulators' recovery efforts will also be illustrated. Part II proceeds with a detailed analysis of the main legal issues involved in this litigation. The arguments typically made by regulators and insurance companies with respect to each exclusion, as well as the court decisions evaluating these arguments, will be explored. Part II will explain the decisions of the courts with respect to these exclusions and conclude that they are generally consistent with established insurance law principles.

In addition to extensive litigation, federal regulators have recently called upon Congress to pass legislation making exclusions directed at regulators illegitimate as a matter of public policy. ${ }^{4}$ Part III of this Comment will argue the opposite: an analysis based

second part covers the corporation for the amounts it is obligated to provide as indemnification for its D\&Os. See DAN L. GoldWASSER, DIREcTORS' AND OFFICERS' LIABILITY INSURANCE AND SELF INSURANCE 32 (1986).

${ }^{3}$ Pub. L. No. 101-73, 103 Stat. 183 (1989) (codified in scattered sections of 12 U.S.C. and 15 U.S.C.). This is a comprehensive law passed to structure the response of the federal government to the S\&L failures and to introduce a number of regulatory reforms. Some of these reforms are discussed in detail below. See infra notes 10-13 and accompanying text.

${ }^{4}$ See infra note 38 and accompanying text. 
on basic insurance-economics principles leads to the conclusion that exclusions barring suits by federal regulators are not only legitimate in the context of the S\&L debacle, but a necessary prerequisite for S\&L managers to obtain private insurance in the first place. In a sentence, the Comment argues that the FDIC is essentially asking insurance companies to insure what should never be insured privately, and that any economically rational insurance company in the early 1980 s would have been very wrong not to exclude regulatory suits.

\section{THE S\&L GRISIS AND D\&O LIABILITY INSURANCE LITIGATION}

The extraordinarily high rate of S\&L failures over the past few years ${ }^{5}$ will impose enormous costs on the federal government and the U.S. taxpayer. The total cost of the S\&L crisis is as yet uncertain, but is invariably measured in the hundreds of billions of dollars. $^{6}$ The federal government, as insurer of the depositors' accounts, is ultimately responsible for reimbursing the majority of these losses. This section will describe both the government's role as insurer of S\&L deposit accounts and its attempts to relieve this burden by suing other potentially responsible parties.

Since the 1930s, the federal government has insured deposits in banks, S\&Ls, and other depository institutions, up to a limit per account that has increased over time, reaching $\$ 100,000$ in $1980 .{ }^{7}$

${ }^{5}$ See S. REP. No. 19, 101st Cong., 1st Sess. 2 (1989) (stating that more than 500 Savings and Loan Associations became insolvent between 1980 and 1988). "That number will be closer to 800 when the [government] takes over its last failed thrift in 1992." Albert V. Casey, A Bigger Bucket for Bailout Fund, N.Y. TIMES, Nov. 22, 1991, at A31.

${ }^{6}$ See Stephen Labaton, New Finance Woes: F.D.I.C. Loss Worse; S. E L. Crisis Deeper, N.Y. TrMES, June 11, 1991, at A1 (reporting that the S\&L rescue is "in such disarray" that the General Accounting Office could not update its 1990 estimate); Michael Quint, New Estimate on Savings Bailout Says Cost Could Be $\$ 500$ Billion, N.Y. TIMES, Apr. 7, 1990, at A1 (reporting the 1990 General Accounting Office's estimate). These estimates seem to increase with time. See G. Christian Hill, A Never Ending Story: An Introduction to the SE'L Symposium, 2 STAN. L. \& POL'Y REV. 21, 23 (1990) (showing a July 1989 estimate of about $\$ 200$ billion and a May 1990 estimate of about $\$ 450$ billion for bailout costs through 1999). Long term costs must take into account the interest the federal government pays on loans incurred toward its obligation. The total costs thus may well exceed a trillion dollars. See id. at 24.

${ }^{7}$ See WHITE, supra note 1 , at 55 . The percentage of all deposits that is insured by the federal government also has increased over time. See Catherine England, Federal Deposit Insurance Reform: The Road Not Taken, 45 CONSUMER FIN. L.Q. REP. 249, 251 (1991) (reporting that between 1985 and 1987 federally insured funds had increased to $75 \%$ of all S\&L deposits). 
Until 1989, deposits in S\&Ls were insured by the Federal Savings and Loan Insurance Corporation (FSLIC), and the S\&Ls themselves were under the chartering, regulatory, and supervisory authority of the Federal Home Loan Bank Board (FHLBB). ${ }^{8}$ In August of 1989, FIRREA, ${ }^{9}$ the major piece of legislation aimed at resolving the failed S\&Ls and recapitalizing the S\&LL deposit insurance fund, became law. FIRREA abolished the FHLBB and the then-insolvent FSLIC, transferred FHLBB's regulatory powers to the Office of Thrift Supervision (OTS), ${ }^{10}$ established the Resolution Trust Corporation (RTC), ${ }^{11}$ whose function is to manage and resolve the failed S\&Ls, and transferred FSLIC's insurance functions to the Federal Deposit Insurance Corporation (FDIC), ${ }^{12}$ a government body already responsible for insuring deposits in commercial banks. ${ }^{13}$

Under this regulatory scheme, when an insured S\&L fails, the government typically becomes its receiver and pays off the insured depositors either directly or indirectly by arranging a transfer of the failed institution's assets to a solvent institution ${ }^{14}$ and supplying

Deposit insurance is a straightforward insurance contract in which a premium is assessed proportionally to the amount of money held in an account and paid to the federal government. In return, the government promises to pay the depositor her insured money if it is lost when a bank or S\&L becomes insolvent. Since the government is obligated, as an insurer, to reimburse any losses up to the $\$ 100,000$ per account limit, it is inaccurate to refer to these payments as a "bailout." In essence, the government is simply honoring insurance contracts into which it had voluntarily entered. See WHITE, supra note 1 , at 163 (asserting that payments by the federal deposit insurance funds were "the direct or indirect honoring of insurance obligations and were not subsidies").

${ }^{8}$ See Paul T. Clark et al., Regulation of Savings Associations Under the Financial Institutions Reform, Recovery, and Enforcement Act of 1989, 45 BUS. LAw. 1013, 1013-14, 1017-18 (1990) (describing generally the regulation of the S\&L industry prior to FIRREA).

${ }^{9}$ Pub. L. No. 101-73, 103 Stat. 183 (1989) (codified in scattered sections of 12 U.S.C. and 15 U.S.C).

${ }^{10}$ See 12 U.S.C. \$ 1437 (Supp. II 1990).

11 See id. $\$ 1441$ a(b)(1) (Supp. II 1990).

12 See id. \$ 1821 a (Supp. II 1990).

${ }^{13}$ See id. $\$ 1811$ (1988). This simply serves as an introduction to the major agencies involved in regulating banks and S\&Ls before and after FIRREA was passed. For comprehensive and detailed analyses of FIRREA, see Clark et al., supra note 8; Daniel B. Gail \& Joseph J. Norton, A Decade's Journey from "Deregulation" to "Supervisory Reregulation": The Financial Institutions Reform, Recovery, and Enforcement Act of 1989, 45 Bus. LAW. 1103 (1990).

14 This is typically done through a so-called Purchase and Assumption Transaction. See FedERAL DEPOSIT INS. CORP., REPORT ON DIRECTORS' AND OFFICERS' LIABILITY INSURANCE AND DEPOSITORY INSTTTUTIONS BONDS PURSUANT TO SECTION 220(B)(3) OF THE FINANCIAL INSTITUTIONS REFORM, RECOVERY, AND ENFORCEMENT ACT OF 
the difference between the lost insured deposits and the total value of the assets transferred. ${ }^{15}$ The government's outlays in each resolution are typically high, especially since failed institutions have been allowed to operate a number of years after they have become insolvent, thus incurring more and more debt. ${ }^{16}$ The resolution costs of a single institution can exceed one billion dollars. ${ }^{17}$

Faced with obligations of such enormous magnitude, government regulators ${ }^{18}$ have attempted to relieve the burden by suing the D\&Os of failed S\&Ls. If the institution's insolvency can arguably be attributed to the negligence or other wrongdoing of such D\&Os, the FDIC, as the S\&L's receiver, can sue on behalf of the institution and its depositors. ${ }^{19}$ Evidence strongly suggests that the D\&Os of many failed S\&Ls frequently made negligent or reckless management and investment decisions. ${ }^{20}$ The FDIC has

1989, at 25 (1991) [hereinafter FDIC REPORT]. For a description of this type of transaction, see Jonathan R. Macey \& Geoffrey P. Miller, Bank Failures, Risk Monitoring, and the Market for Bank Control, 88 CoLUM. L. REV. 1153, 1182-84 (1988).

${ }^{15}$ See FDIC REPORT, supra note 14, at 25.

16 The average duration of insolvency for institutions resolved in 1988 was three and one-half years. See James R. Barth \& R. Dan Brumbaugh, Jr., The Rough Road from FIRREA to Deposit Insurance Reform, 2 STAN. L. \& POL'Y REV. 58, 64 (1990).

17 See FDIC REPORT, supra note 14, at 25.

18 "Government regulatory agencies" refers to the FSLIC before FIRREA, and the FDIC since. Hereinafter, "the FDIC" will be used when referring to both.

19 For a general overview of some of the issues arising in litigation between regulators and S\&L directors and officers, see WILLIAM E. KNEPPER \& DAN A. BAILEY, LIABILTTY OF CORPORATE OFFICERS AND DIRECTORS § 12.08-.09 (4th ed. 1988 \& Supp. 1990); Judy Y. Barrasso, Litigating Claims Against Directors and Officers of Failing Financial Institutions, in FAILING FinANCIAL INSTITUTIONS 59, 59 (American Law Inst.Am. Bar Ass'n Committee on Continuing Professional Educ. ed., 1991); Danny Clearman, Comment, FDIC and FSLIC Pursuit of Claims Against Officers, Directors, and Others Involved wilh Failed Lenders, 58 Miss. L.J. 89, 102-20 (1988); Thomas P. Fitch, The Heat is On, U.S. BANKER, June 1985, at 32.

The prevalence of claims against D\&Os should not imply that deposits were embezzled by S\&L managers. Lack of care in the performance of their duties is sufficient grounds for D\&CO liability. See WHTTE, supra note 1, at 198.

${ }^{20}$ See JAMES R. ADAMS, THE BIG FIX: INSIDE THE S\&L SCANDAL passim (1990); MARTIN MAYER, ThE GREATEST-EVER BANR RobBery passim (1990); Joseph A. Grundfest, Lobbying into Limbo: The Political Ecology of the Savings and Loan Crisis, 2 STAN. L. \& POL'Y REV. 25 (1990). The FDIC reported recently that, "[i]n the only systematic study" of bank management, the government found that more than $90 \%$ of the banks closed by the government between 1979 and 1987 suffered from "significant mismanagement," $35 \%$ from "insider abuse," and $11 \%$ from fraud. FDIC REPORT, supra note 14, at 26.

With that knowledge, Congress expanded governmental enforcement authority by passing FIRREA. See KNEPPER \& BAILEY, supra note 19, § 12.02 (Supp. 1990); Clark et al., supra note 8, at 1028-31 (describing the expanded enforcement powers of the OTS and the FDIC). 
forcefully pursued many of these D\&Os with lawsuits alleging breach of the duty of care and seeking tens of millions of dollars, often with great success. ${ }^{21}$ The FDIC has also sought, with equal vigor, to recover from failed institutions' attorneys and accountants in malpractice suits. ${ }^{22}$

Still, the FDIC does not sue every time it suspects wrongdoing by an officer, director, or outside professional; rather, it pursues its possible claims only when it appears cost effective to do so. " [E]ven when there may be a good case on the merits, the FDIC will normally not bring a civil suit against officers and directors when

${ }^{21}$ See FDIC Considers Suits Against SEL, Bank Officials in 1,300 Institutions, 55 Banking Rep. (BNA) No. 3, at 97, 9'7 (July 16, 1990) (noting that "[i]n the first quarter of 1990 alone, the FDIC and RTC recovered more than $\$ 100$ million"); FDIC Official Defends Legal Division, Says Unit Cooperating with Justice Dept., 57 Banking Rep. (BNA) No. 22, at 903, 903 (Dec. 2, 1991) [hereinafter Legal Division] ("The professional liability section, which is responsible for action against institution directors, officers, and other professionals, has recovered $\$ 877$ million since $1988 \ldots$. . "); FSLIC Wins $\$ 86$ Million Judgement in Defunct Louisiana Thrift Case, 52 Banking Rep. (BNA) No. 24, at 1291, 1291 (June 12, 1989); Mark A. Hofmann, Bank's DEOO Insurers Reach Tentative Pact, BUS. INS., Nov. 7, 1988, at 11 (discussing a proposed $\$ 60$ million settlement in the FDIC suit against Continental Illinois Corporation); Marianne Lavelle, FDIC: Tough Choices on Firms, NAT'L L.J., Nov. 19, 1990, at 3 ("With 800 law firms handling 100,000 suits at a price tag of $\$ 500$ million this year, FDIC is in charge of a bigger litigation program than any U.S. regulatory agency ever has been called upon to manage."); RTC Seeks $\$ 140$ Million in DEO Lawsuit, Names Ariz Gov. Symington as Defendant, 57 Banking Rep. (BNA) No. 25, at 1053 (Dec. 23, 1991).

22 See, e.g., Linda Himelstein, Jones, Day Adopts Aggressive No-Settle Policy, N.J. L.J., Apr. 18, 1991, at 5 (stating that the RTC sought $\$ 50$ million from the law firm of Jones, Day, Reavis, and Pogue in a malpractice suit); Rita H. Jensen, RTC Sues Jones Day, NAT'L L.J., Apr. 15, 1991, at 2 (reporting a regulator suit against Jones, Day, Reavis, and Pogue as well as other attorneys); Stephen Labaton, U.S. Moves to Freeze Assets of Law Firm for SE'L Role, N.Y. TIMES, Mar. 3, 1992, at A1 (describing action against Kaye, Scholer, Fierman, Hays \& Handler); Walter Lucas, Malpractice Rate Hikes on the Horizon, Again: The $S \mathcal{E} L$ Crisis and Economic Downturn Are Cited as Triggers, N.J. L.J., Jan. 31, 1991, at 3 (stating that "federal regulators in the past three years have recovered [some] $\$ 95$ million from attorneys who represented banks and [S\&Ls]"); Deborah Shalowitz, Insurers to Pay \$50 Million to FSLIC in EE'O Settlement, BUS. INS., Aug. 15, 1988, at 2 (reporting a $\$ 50$ million recovery against a law firm); Sherry R. Sontag, Soured Deals Snag More Professionals, NAT'L L.J., Feb. 4, 1991, at 1 (reporting an increase in regulator suits against professionals in order to replenish the deposit insurance funds).

Congress specifically complained of the perceived poor performance of outside accountants in assessing S\&L's' financial position and dealings. See, e.g., Failure of Independent CPA's to Identify Fraud, Waste, and Mismanagement and Assure Accurate Financial Position of Troubled SE'Ls: Hearing Before the House Committee on Banking, Finance and Urban Affairs, 101st Cong., 1st Sess. 1-3 (1989) [hereinafter Accountant Hearing] (citing survey of failed S\&LLs that revealed 6 of 11 were not audited in accordance with professional standards). 
the anticipated recovery is not expected to exceed the attorneys' fees and other costs of pursuing the case." 23

The FDIC typically hires private law firms to litigate its claims, and these firms' fees have tended to be exorbitant, ${ }^{24}$ increasing the FDIC's costs. Furthermore, the targets of the FDIC's suits may have modest holdings, especially when compared to the magnitude of the claims the FDIC advances. ${ }^{25}$ This is particularly true for directors of S\&Ls, whose incomes as directors are typically low to moderate. ${ }^{26}$ In deciding whether a case would be cost effective, the FDIC considers the defendants' total assets, including the D\&Os' liability insurance policies. ${ }^{27}$ These policies are frequently D\&Os' most important assets, and, as one commentator asserted, "may even encourage litigation that might not have been brought but for the insurance." 28

As the FDIC became more aggressive in pursuing D\&Os of failed S\&Ls in the mid-to-late $1980 \mathrm{~s}$, the D\&O insurers attempted to prevent reimbursement of the FDIC for losses incurred by D\&Os of failed institutions, turning to two exclusions in their policies, the regulatory exclusion and the insured $v$. insured exclusion. ${ }^{29}$ The language of the typical regulatory exclusion makes clear its purpose

23 FDIC REPORT, supra note 14, at 27.

24 See Jeff Gerth, U.S. Said to Squander Millions for Legal Work on the Bailout, N.Y. TIMES, Nov. 16, 1991, at 1 (estimating that the FDIC would spend $\$ 700$ million on private legal help in 1991).

${ }^{25}$ See supra notes 21-22.

${ }^{26}$ See Fitch, supra note 19, at 32 (" [T] he risks associated with being a director have suddenly become massive, and the costs associated with those risks can be mindboggling. Even as remuneration remains low.").

27 The FDIC has outlined their process of case selection as follows:

In determining whether a meritorious claim would be cost effective the FDIC looks at: (1) the appropriate defendants' assets and liabilities (and what they could keep in bankruptcy, taking into account, for example, the almost unlimited "homestead" exemption in Texas and certain other states) and (2) applicable directors' and officers' liability insurance (or in the case of fraud or theft, any applicable bond policy). Also, defendants do not always have the financial resources they are believed to have when cases are filed. D\&O suits are not brought, however, unless it is expected that cases of that type will, on average, yield significantly more than they cost.

FDIC REPORT, supra note 14, at 27.

${ }^{28}$ Robert S. Lavet, Insurance Companies: The Last Decp Pocket in the SE'L Crisis, 58 DEF. Couns. J. 211,211 (1991).

${ }^{29}$ See Russell Leibson \& Paula LaBrie, Running for Cover: Insurers Are Struggling to Escape Liability for the Acts of Executives of Failed SE'Ls Through Exclusion Provisions in 'DEOO' Policies, THE RECORDER, Aug. 12, 1991, at 4 (addressing a developing trend of exclusion clauses in insurance policies and the willingness of the courts to enforce them). 
is specifically to deny coverage to federal deposit insurers and related regulatory agencies:

[this policy does not cover] any action or proceeding brought by or on behalf of the Federal Deposit Insurance Corporation, the Federal Savings and Loan Insurance Corporation, any other depository insurance organization, the Comptroller of the Currency, The Federal Home Loan Bank Board, or any other national or state regulatory agency (all of said organizations and agencies hereinafter referred to as "Agencies"), including any type of legal action which such Agencies have the legal right to bring as receiver, conservator, liquidator or otherwise; whether such action or proceeding is brought in the name of such Agencies or by or on behalf of such Agencies in the name of any other entity or solely in the name of any Third Party. ${ }^{30}$

The insured v. insured exclusion denies coverage when one insured under the $\mathrm{D} \& \mathrm{O}$ policy is the defendant in a liability suit brought by another person or entity insured under the same policy. An insured v. insured exclusion might provide that "it is agreed that the Company shall not be liable to make any payment for loss in connection with any claim or claims made against the Insured(s) by any other Insured(s) as defined in the Policy, except for shareholder's derivative actions. ${ }^{\text {31 }}$ The exclusion typically applies when a corporation sues one or more of its own D\&Os in an effort to trigger coverage. ${ }^{32}$ Insurers attempt to apply the exclusion to the FDIC by arguing that the agency becomes an "insured" when it acts as receiver for the failed S\&L.

While a variety of coverage issues are involved in $\mathrm{D} \& \mathrm{O}$ insurance litigation in general, the validity and effect of these two

${ }^{30}$ Continental Casualty Co. v. Allen, 710 F. Supp. 1088, 1097 (N.D. Tex. 1989) (quoting the insurance policy endorsement at issue).

${ }^{31}$ St. Paul Fire \& Marine Ins. Co. v. FDIC, 765 F. Supp. 538, 548 (D. Minn. 1991) (quoting the insurance policy at issue), affd, 968 F.2d 695 (8th Cir. 1992). Some policies do not have an exception for shareholder derivative suits. For example, see the policy at issue in Mt. Hawley Ins. Co. v. FSLIC, 695 F. Supp. 469, 481 (C.D. Cal. 1987).

32 Both the corporation and the corporation's executives are insured by typical D\&O policies. See supra note 2. Absent any exclusion, a corporation's suit against its own executives may be covered. See, e.g, National Union Fire Ins. Co. v. Seafirst Corp., 662 F. Supp. 36, 39 (W.D. Wash. 1986) (holding that an insurance policy that had no insured v. insured exclusion covered damages awarded in a suit by shareholders against the corporation's directors), affd sub nom. Davis Wright \& Jones v. National Union Fire Ins. Co., 897 F.2d 1021 (9th Cir. 1990). Generally, the insured v. insured exclusion avoids collusion between the corporation and the executives and prevents a corporation from triggering coverage merely by filing suit. 
exclusions are repeatedly and almost exclusively3 the central issues in high-stakes $\mathrm{D} \& \mathrm{O}$ coverage litigation. ${ }^{34}$ Because of its concern about keeping all possible sources available to replenish the deposit insurance fund, the FDIC has contested these exclusions in court attempting either to prevent their applicability to itself or to invalidate them altogether. ${ }^{35}$ The stakes in D\&O cases may well run into the tens of millions of dollars. ${ }^{36}$ The FDIC, therefore, continues to combat the effectiveness of these exclusions. ${ }^{37}$ Most recently, the FDIC released a report specifically addressing these exclusions and recommending that Congress legislatively prohibit the enforcement of these clauses against the FDIC. ${ }^{38}$ For their part, the insurers continue to defend these exclusions, motivated by the fear of incurring substantial liabilities if they do not. ${ }^{39}$

Litigation over the enforceability of exclusion clauses seems likely to extend beyond D\&O liability insurance policies. Attorney

${ }^{33}$ All regulatory exclusion cases have involved the FDIC, FSLIC, and similar deposit insurance regulatory agencies.

${ }^{34}$ See Lavet, supra note 28 passim (detailing the prominence of these two exclusions in S\&L coverage litigation); Leibson \& LaBrie, supra note 29 passim (same).

${ }^{35}$ See Lavet, supra note 28 passim.

${ }^{36}$ See supra notes 21-22.

${ }^{37}$ In response to public and congressional pressure, the FDIC is currently aggressively pursuing legal means to relieve the burden on the deposit insurance fund. See Alan J. Whitney, Getting Afler the Savings and Loan Crooks, N.Y. TuMEs, July 11,1990 , at A18 (director of the FDIC's Office of Corporate Communications describing the FDIC's commitment to pursue S\&L executives, lawyers, other professionals, and "those who insure their conduct"). In a House hearing on FIRREA, Congressman LaFalce stated:

There is one thing I would definitely like to see us do. Everybody talks about going after the crooks in the S\&L industry, and we should. . . . But I would also like to see us go after the inept, the negligent officers and directors of these institutions for whatever civil liability they may be responsible for.

Almost all of them, I would assume; would have directors and officers liability insurance. Therefore, they would be covered in extremely high amounts for whatever cause of actions we could be successful in bringing.

See Accountant Hearing, supra note 22, at 6.

${ }^{38}$ See FDIC REPORT, supra note 14 , at 19-22. The report was released in September 1991. See id.; see also DE'O Study Says Legislative Action Needed to Address Court Decisions Against FDIC, 57 Banking Rep. (BNA) No. 13, at 511, 512-13 (Sept. 30, 1991) (recounting the suggestion that the timing of the report's release was planned to influence bank legislation then pending in Congress).

${ }^{39}$ See FDIC REPORT, supra note 14, app. A at 5-11 (summarizing D\&O insurers' comments submitted to FDIC defending the exclusion); Lavet, supra note 28, at 211 (referring to the suggestion that the refusal by some courts to enforce the exclusions "is simply a politically expedient way to pass part of the costs of the thrift and bank bailouts on to the insurance companies"). 
malpractice insurers have started scrutinizing more carefully the policies they underwrite or renew for attorneys who worked in the S\&L industry. ${ }^{40}$ Motivated by the massive potential liabilities ${ }^{41}$ and the aggressiveness of the FDIC in pressing its claims against $\mathrm{D} \& \mathrm{O}$ liability carriers, ${ }^{42}$ attorney malpractice insurers have already obtained the permission of insurance commissioners in several states to sell legal malpractice policies containing regulatory exclusions similar to those in D\&O policies. ${ }^{43}$ Since the FDIC seems determined to challenge their applicability, ${ }^{44}$ the litigation over regulatory exclusion clauses in the S\&L context has perhaps only just begun. The balance of this Comment will analyze the legal and policy issues that will be the focal point of this high-stakes insurance coverage litigation. ${ }^{45}$

\section{THE D\&O POLICY EXCLUSIONS IN THE COURTS}

Both before and after FIRREA was passed, an insolvent S\&L (or bank) typically fell under the receivership or conservatorship of federal regulatory agencies. FIRREA granted the FDIC the

${ }^{40}$ See Barbara Franklin, Cutting Their Losses: Insurers Seek to Limit Exposure Due to Lawyers, N.Y. L.J., June 27, 1991, at 5 (describing how insurers scrutinize lawyers who take positions on S\&Ls' boards of directors); Linda Himelstein, Insurers Cutting Ties to Counsel in the SEL Fiasco, THE RECORDER, May 1, 1991, at 1 (describing how insurers are increasingly including exclusion clauses in attorney malpractice policies).

${ }^{41}$ See Himelstein, supra note 40, at 10 ("[I]nsurers seeking exemptions say the financial impact from thrift-related litigation could simply overwhelm them.").

42 See id. ("Insurance] industry advocates say the government, with its power and resources to litigate endlessly, is unlike any other plaintiff."); see also supra note 22 (listing examples of major awards against attorneys and accountants in malpractice suits brought by regulatory agencies).

${ }^{43}$ See Himelstein, supra note 40 , at 1 (stating that several states already allow the exclusions and that others may follow).

44 Mr. John Thomas, FDIC Associate General Counsel in charge of professional liability matters, states: "My expectation is that we will attack [the regulatory exclusions] .... This has the potential to make millions of dollars of difference if these exclusions are effective in precluding coverage .... The effect would be to reduce the [government's] net recovery on attorney malpractice cases. Taxpayers clearly pick up that loss." Id. at 10.

${ }^{45}$ The discussion is confined to the context of the S\&L crisis and its particular character. But one already finds suggestions that the regulatory exclusion and related matters may be litigated in wholly different contexts. See, e.g., William S. Biel, Comment, Whistling Past the Waste Site: Directors' and Officers' Personal Liability for Environmental Decisions and the Role of Liability Insurance Coverage, 140 U. PA. L. REV. 241, 277-79 (1991) (stating that "[u]nder close comparison, the provisions of the D\&eO liability insurance policies' pollution exclusion clauses appear analogous to a regulatory agency exclusion," and suggesting that the two might share the same fate). 
authority over S\&Ls previously held by the FSLIC. ${ }^{46}$ Specifically, under FIRREA, the FDIC is empowered in its capacity as receiver or conservator to resolve the insolvent institution it now controls ${ }^{47}$ and succeed to "all rights, titles, powers, and privileges of the insured depository institution, and of any stockholder, member, accountholder, depositor, officer or director of such institution with respect to the institution and [its] assets. ${ }^{n 8}$ The FDIC has the power to "operate the insured depository institution with all the powers of the members or shareholders, the directors and the officers," 49 "collect all obligations," of the institution. ${ }^{51}$ The FDIC may also repudiate certain burdensome contracts the S\&L entered into before receivership or conservatorship, ${ }^{52}$ and in general terms may enforce the institution's contracts. ${ }^{53}$ The FDIC also must "pay all valid obligations ${ }^{\text {54 }}$ incurred by the S\&L.

In its capacity as receiver or conservator, the FDIC attempts to recover as much money as possible for the doomed S\&L through director, officer, and other professional liability lawsuits. This litigation frequently amounts to suing defendants' insurance carriers directly or suing defendants for the money they may have recovered from their insurance carriers. Although the FDIC and D\&Os are opponents in D\&O duty of care and negligence litigation, they are pitted together against the insurer in the policy coverage disputes. This litigation raises the typical legal squabbles encountered in most insurance coverage cases, whether it be a dispute over an alleged misrepresentation on the insured's application for insurance, ${ }^{55}$ or

16 See 12 U.S.C. § 1821(c) (Supp. II 1990).

17 See generally Gail \& Norton, supra note 13, at 1134-38 (explaining the FDIC's powers under FIRREA).

1812 U.S.C. § 1821(d)(2)(A)(i) (Supp. II 1990).

${ }^{49} I d$. \$ 1821(d)(2)(B)(i) (Supp. II 1990).

${ }^{50}$ Id. $\$ 1821$ (d)(2)(B)(ii) (Supp. II 1990).

${ }^{51}$ Id. $\$ 1821$ (d)(2)(B)(iii) (Supp. II 1990).

52 See id. \$ 1821(e)(1) (Supp. II 1990).

53 See id. \$ 1821(e)(12) (Supp. II 1990). This specific provision will be visited again in this Comment in detail. See infra notes 93-100 and accompanying text.

54 12 U.S.C. $\$ 1821$ (d)(2)(H) (Supp. II 1990).

35 Insurers may be able to rescind a policy if the insured's policy application contains a material misrepresentation or an omission of a material fact. See, e.g., Atlantic Permanent Fed. Sav. \& Loan Ass'n v. American Casualty Co., 839 F.2d 212, 216-17 (4th Cir. 1988) (holding the particular dishonesty exclusion at issue ambiguous and requiring a judgment or adjudication for the exclusion to take effect), cert. denied, 486 U.S. 1056 (1988). See generally 12A JoHN A. APPLEMAN \& JEAN APPLEMAN, INSURANCE LAW AND PRACTICE \$§ 7291-7305 (rev. ed. 1981 \& Supp. 1991) (discussing 
the definition of "claim"56 or "occurrence"57 under the policy. Litigation of these matters turns upon principles established in prior precedent, thus the fact that the FDIC is involved in this litigation in the S\&L context has not typically created new law. On the other hand, the issues raised by exclusion litigation are unique to the $\mathrm{D \& O}$ insurance coverage cases. This Part will examine these issues and the cases that raise them.

\section{A. The Insured v. Insured Exclusion Litigation}

As stated above, this exclusion denies coverage when one insured under the policy is the defendant in a liability suit brought by another person or entity insured under the same policy. ${ }^{58}$ Insurers attempt to use this exclusion to deny coverage in suits brought by the FDIC by arguing that, as receiver or conservator, it steps into the shoes of the insured $S \& L^{59}$ and thus should likewise assume the designation of an insured. ${ }^{60}$ That is, when the FDIC,

representations, including the duty of disclosure, materiality, and fraud).

${ }_{36} \mathrm{D} \& \mathrm{O}$ insurance typically does not cover events occurring during the policy period, but rather covers claims made (and sometimes also reported to the insurer) during that period. Under a claims-made insurance policy:

[T]he insurer agrees to assume liability for acts or omissions of the type covered by the policy regardless of when they occurred, if (1) the claim arising out of the act or omission was made during the policy period, or (2) notice was given to the insurer within the policy period as to an occurrence which may subsequently give rise to a claim.

FSLIC v. Burdette, 718 F. Supp. 649, 651-52 \& n.2 (E.D. Tenn. 1989). Since the insurer's liability hinges on whether a "claim" has been made, the scope of the definition of this term is often a contested matter. See, e.g., Mt. Hawley Ins. Co. v. FSLIC, 695 F. Supp. 469, 479-80 (C.D. Cal. 1987) (holding that letters from the FHLBB that imposed restrictions and threatened enforcement action amounted to a claim).

${ }^{37}$ Insurers typically provide reimbursement up to a limit per single loss, making the definition of a loss (or an "occurrence") also a contested matter. See, e.g., Eureka Fed. Sav. \& Loan Ass'n v. American Casualty Co., 873 F.2d 229, 234-35 (9th Cir. 1989) (holding that a single loan policy may have caused multiple loan losses such that the insurance limit of $\$ 20$ million should apply to each one of them). A related issue involves the inclusion of legal defense costs within the stated policy limit. See, e.g., Burdette, $718 \mathrm{~F}$. Supp. at 660-61 (holding that defense costs should be advanced as they become due).

58 See supra notes $81-32$ and accompanying text. According to the FDIC, "[n]eedless to say, the FDIC's only interest in this exclusion is to prevent its illegitimate use against the FDIC or any other receiver, liquidator, or conservator." FDIC REPORT, supra note 14, at 103.

${ }^{59} \mathrm{D \& O}$ insurance policies typically also indemnify the S\&L itself for the amounts it is obligated to provide as indemnification for its D\&Os. See supra note 2.

${ }^{60}$ See, e.g., American Casualty Co. v FSLIC, 704 F. Supp. 898, 900 (E.D. Ark. 1989) 
representing the interests of the insured $S \& L$, sues a director or officer clearly insured under the policy, the exclusion presumably should be triggered. In reply, the FDIC (and the insured D\&Os) argues that the exclusion is intended to preclude an active and open S\&L from triggering coverage by merely suing one of its executives, and that, in any case, the FDIC acts not only for the failed institution but also for the failed S\&L's creditors and shareholders, parties clearly uninsured by the D\&O policy. ${ }^{61}$

Most courts have held for the FDIC under the insurance law doctrine of contra proferentum. This doctrine stands for the proposition that if a certain term or clause in an insurance contract is found to be ambiguous, that is, subject to more than one reasonable interpretation, the court chooses the interpretation most favorable to the insured. Some variation of this doctrine is the law in every state. ${ }^{62}$ Therefore, although these cases are decided under the insurance laws of different states, the analysis is analogous in all the cases.

Specifically, in the context of the D\&O insurance policy litigation, courts have found the insured v. insured exclusion ambiguous, on the grounds that it is not clear whether federal regulators should be deemed an insured under the clause. Some courts have held the clause ambiguous based on the definition of "insured" provided in the policy. ${ }^{63}$ Usually, though, the court notes that the FDIC does not merely act as legal successor to the institution, but also represents the interests of the institution's shareholders and creditors, and in that capacity it cannot be deemed an insured under the policy. ${ }^{64}$

("American claims that the FSLIC, as receiver, stands in the shoes of [the S\&L], for purposes of the actions against the former officers and directors . . . because it ... brought the underlying actions "for the benefit of [the S\&L]." (citing 12 U.S.C. $\S 1789$ (b) (1988)).

61 See FDIC REPORT, supra note 14, at 29.

62 Ambiguous clauses are to be "liberally construed in favor of a policyholder or beneficiary thereof, whenever possible, and strictly construed against the insurer in order to afford the protection which the insured was endeavoring to secure when he applied for the insurance." 13 APPLEMAN \& APPLEMAN, supra note 55, § 7401 (rev. ed. 1976 \& Supp. 1991).

${ }^{63}$ See, e.g., St. Paul Fire \& Marine Ins. Co. v. FDIC, 765 F. Supp. 538, 548 (D. Minn. 1991) (" $[$ The] policy definition of Insured includes 'a corporation(s) . . . and ... subsidiaries .... Thus while it is clear that under the policy the [institution] is an Insured, it is by no means clear that Insured includes the FDIC which took the bank over as a receiver.") (quoting the policy at issue), affd, $968 \mathrm{F.2d} 695$ (8th Cir. 1992).

${ }^{61}$ See FDIC v. Zaborac, 773 F. Supp. 187, 144 (C.D. Ill. 1991) (holding that "the 
Only a handful of courts have held the exclusion effective against the FDIC, accepting the insurers' argument that the FDIC assumes the failed S\&L's posture as an insured under the policy when it takes control of the institution. In other words, these courts hold that the exclusion unambiguously bars suits brought by the institution's receivers or conservators like the FDIC. ${ }^{65}$

Thus, it appears that the FDIC is prevailing in the majority of these suits. ${ }^{66}$ As a result, although insurers have continued to

FDIC does not merely stand in the shoes of [the director or officer], it can also stand in the shoes of the shareholders"); American Casualty Co. v. Baker, 758 F. Supp. 1340, 1349 (C.D. Cal. 1991); Fidelity \& Deposit Co. v. Zandstra, 756 F. Supp. 429, 432 (N.D. Cal. 1990); Branning v. CNA Ins. Cos., 721 F. Supp. 1180, 1184 (W.D. Wash. 1989); American Casualty Co. v. FSLIC, 704 F. Supp. 898, 900-02 (E.D. Tenn. 1989); FDIC v. National Union Fire Ins. Co., 630 F. Supp. 1149, 1157 (W.D. La. 1986); see also American Casualty Co. v. FDIC, 713 F. Supp. \$11, 316 (N.D. Iowa 1988) ("Courts which have analyzed the role of FDIC corporate have recognized for over forty years that the FDIC does not strictly 'step into the shoes' of a failed bank.") (citing D'Oench, Duhme \& Co. v. FDIC, 315 U.S. 447, $472-73$ (1942) (Jackson, J., concurring)). "FIRREA's codification of the FDIC's succession to the rights and powers of shareholders and depositors of failed institutions has strengthened the FDIC's position on this exclusion ...." FDIC REPORT, supre note 14, at 105 n.128.

A small number of courts take this analysis one step further to argue that the FDIC does not only bring claims on behalf of depositors, shareholders, and creditors, but also on behalf of "the [deposit] insurance fund." Branning, 721 F. Supp. at 1184. As such, the FDIC incurs costs stemming from its statutory responsibility to resolve the failing institution. Thus, "[a]ny recovery by FDIC in the underlying actions against the officers and directors is properly understood as a reimbursement for its loss incurred on behalf of the third parties .... In a very real sense, therefore, it can be understood as possessing independent claims against the directors and officers." Zandstra, 756 F. Supp. at 433.

A few of the courts that adopted the FDIC's interpretation of the insured $v$. insured exclusion went even further. For example, in Zandstra, the court stated that the intent behind the insured v. insured exclusion is to prevent collusive suits between a corporation and its executives, a goal that is wholly inapplicable to federal regulators. See id. at 431 . But see FDIC v. Zaborac, 773 F. Supp. 137, 143 (C.D. Ill. 1991) ("Before a court can start divining the intent behind a clause such as this one, the Court must determine that the clause was ambiguous.").

65 See Gary v. American Casualty Co., 753 F. Supp. 1547, 1550 (W.D. Okla. 1990) ("FDIC's construction of this exclusion [is] strained and unreasonable."); Mt. Hawley Ins. Co. v. FSLIC, 695 F. Supp. 469, 483 (C.D. Cal. 1987). The latter case held that even if the exclusion were ambiguous, the doctrine of reasonable expectations would not benefit the government. The court stated that the insured executives could not have reasonably expected that they were being insured against "the consequences of breaching their duty to the corporation," but presumably only against third-party suits. Id. at 484 .

${ }^{66}$ See FDIC REPORT, supra note 14, at 104 (indicating that as of September 1991, the courts held for the insurers in only three out of seventeen cases with a final decision).

It is notable that the courts did not strike the exclusion or invalidate it on its face on public policy grounds. The courts simply analyzed the language of the insured $v$. 
advance this defense in litigation with the FDIC, the insured v. insured exclusion has lost much of its significance in the S\&L context. For this reason, much of the legal and policy discussion in this Comment concentrates on the regulatory exclusion.

\section{B. The Regulatory Exclusion}

The regulatory exclusion explicitly denies coverage for suits brought by the FDIC and other regulatory agencies. Accordingly, the insurers argue that courts cannot possibly hold the exclusion ambiguous, and should therefore enforce the exclusion as written to preclude coverage for any suit brought by the FDIC. In the typical case, the FDIC counters by arguing that the regulatory exclusion can still be found ambiguous, and thus should be construed in the insureds' (and thus its own) favor. Alternatively, if the exclusion is found unambiguous, the FDIC argues it should be voided altogether on public policy grounds. That is, the FDIC argues that to allow the exclusion to bar its suit impairs its ability to represent the failed institution now under its sole control, as well as the institution's creditors and shareholders-a result that is in conflict with the FDIC's statutory right and obligation to resolve the insolvent institution. ${ }^{67}$

Like the courts' construction of the insured v. insured exclusion clause, interpretation of the regulatory clause has varied somewhat. Some courts have held the wording of the exclusion to be ambiguous. In one case, for example, the court concluded that a policy excluding coverage for "any action or proceeding brought by or on behalf of the Federal Deposit Insurance Corporation'm68 and similar agencies did not reach an action continued and maintained by the regulatory agency, but originally filed by the failed institution. ${ }^{69}$ Similarly, in another case, interpreting atypical exclusion language denying coverage for claims due to "any action or proceeding resulting from violation of any laws, [or] regulations ...

insured exclusion, and concluded that it does not apply to the FDIC. In other words, the courts did not rescrt to specific public policy arguments to determine the effectiveness of the clause. Instead, their analyses adhered to the established insurance law doctrines that existed when these insurance contracts were negotiated. The relevance of this point will become clear in the next section in which the case law interpreting the regulatory exclusion clause is analyzed.

${ }^{6}$ See FDIC REPORT, supra note 14, at 32.

${ }^{68}$ American Casualty Co. v. FSLIC, 683 F. Supp. 1183, 1184 (S.D. Ohio 1988) (quoting the insurance policy at issue).

${ }^{69}$ See id. at 1185. 
as promulgated by [depository institution regulators] or any other national or state regulatory agency," 70 the court held the exclusion ambiguous because it was extremely broad and could be read as excluding all claims by any litigant-the policy would therefore be entirely valueless. ${ }^{71}$ Most recently, another court held the exclusion to be ambiguous because "it is unclear whether this exclusion was intended to apply to the FDIC when acting in multiple capacities," such as depositor, creditor, or shareholder. ${ }^{72}$

Most courts, however, have held the regulatory exclusion unambiguous. Consequently, absent any other ground for its invalidation, they have applied the exclusion on its terms. ${ }^{73}$ For example, in Gary v. American Casualty Co. ${ }^{74}$ the court state

Although the language "based upon or attributable to" is awkward ... the Court finds the FDIC's construction of this exclusion to be strained and unreasonable. Reading the endorsement as a whole, ... it is clear that the insured's intent was to exclude coverage for any loss resulting from any action brought by

${ }^{70}$ American Casualty Co. v. FSLIC, 704 F. Supp. 898, 902 (E.D. Ark. 1989) (quoting the insurance policy at issue).

${ }^{71}$ See id. at 903 \& n.5.

72 FDIC v. Mijalis, No. CIV A 89-1316, 1992 WL 172677, at *14 (W.D. La. June 30, 1992).

Another court held the regulatory clause at issue ambiguous because excluding losses "based upon or attributable to" claims brought by a regulatory agency does not reach the FDIC's actions themselves, but rather reaches other, "secondary" suits that are somehow based upon the agency's primary actions. FSLIC v. Mmahat, No. 86-5160, 1988 U.S. Dist. LEXIS 1825, at *8, *6-*7 (E.D. La. Mar. 3, 1988) (quoting the policy at issue), affd in part and remanded in part, $907 \mathrm{F.2d} 546$ (5th Cir. 1990), cert. denied, 111 S. Ct. 1387 (1991). Another district court adopted this reasoning then subsequently reversed itself. See American Casualty Co. v. FDIC, 677 F. Supp. 600, 603-04 (N.D. Iowa 1987), rev'd on this point, No. 86-4018, 1990 U.S. Dist. LEXIS 6065, at *50 (N.D. Iowa Feb. 26, 1990), aff'd in part and rev'd in part, 944 F.2d 455 (8th Cir. 1991).

${ }^{73}$ See FSLIC v. Shelton, 789 F. Supp. 1355, 1357-60 (M.D. La. 1992); FDIC v. Zaborac, 773 F. Supp. 137, 141 (C.D. Ill. 1991) ("Clearly, this exclusion was intended to bar any action brought or maintained by the FDIC ....."); Powell v. American Casualty Co., 772 F. Supp. 1188, 1191 (W.D. Okla. 1991); St. Paul Fire \& Marine Ins. Co. v. FDIC, 765 F. Supp. 538, 549 (D. Minn. 1991), affd, 968 F.2d 695 (8th Cir. 1992); American Casualty Co. v. Baker, 758 F. Supp. 1340, 1347 (C.D. Cal. 1991); Gary v. American Casualty Co., 753 F. Supp. 1547, 1550-51 (W.D. Okla. 1990), affd, Nos. 91-6147, 91-6148, 1992 U.S. App. LEXIS 20536 (10th Cir. Sept. 1, 1992); Continental Casualty Co. v. Allen, 710 F. Supp. 1088, $1097-98$ (N.D. Tex. 1989); McCuen v. International Ins. Co., No. 87-54-D-1, 1988 U.S. Dist. LEXIS 17624, at *13 (S.D. Iowa Sept. 29, 1988), remanded on other grounds, 946 F.2d 1401 (8th Cir. 1991).

74753 F. Supp. 1547 (W.D. Okla. 1990). 
or on behalf of the FDIC in any capacity against a bank director or officer. ${ }^{75}$

Similarly, another court held that "[s]imply because the FDIC did not technically 'bring' this action and is only 'maintaining' this action does not mean that the FDIC can escape the plain intent of the regulatory exclusion. ${ }^{76}$

Unlike the courts dealing with the insured v. insured exclusion, a majority of district courts have held the regulatory exclusion unambiguous. These courts must therefore weigh the merits of the government's public policy argument. As briefly stated earlier, ${ }^{77}$ in the typical regulatory exclusion case, the FDIC argues that enforcement of the exclusion would impede the fulfillment of the agency's federal statutory obligation to resolve the insolvent institution and therefore should be voided on its face.

Three district courts, all prior to the passage of FIRREA, held that the regulatory exclusion violated public policy and was therefore void. ${ }^{78}$ Conversely, two courts explicitly held against the government. ${ }^{79}$ In Branning v. CNA Insurance Cos., the court reasoned that if the exclusion were valid, "all of [the regulatory agency's] claims, regardless of their origin or status under the policy, would not be covered simply because [the agency] ... prosecuted the claim. Private parties to an insurance contract may not frustrate the Congressional purpose behind receivership by annulling [the agency's] federal powers. ${ }^{n 0}$ In contrast, the court in Continental Casualty Co. v. Allen asserted that "the most often found violators of public policy are contracts that induce criminal conduct or are contrary to statutory law. ${ }^{81}$ The court explained that to hold that the exclusion violated public policy requires an

75 Id. at $1550-51$ (footnote omitted).

76 Zaborac, 773 F. Supp. at 141.

77 See supra note 66 and accompanying text.

${ }^{78}$ See Branning v. CNA Ins. Cos., 721 F. Supp. 1180, 1183-84 (W.D. Wash. 1989); FSLIC v. Mmahat, No, 86-5160, 1988 U.S. Dist. LEXIS 1825, at *5 (E.D. La. Mar. 3, 1988), affd in part and remanded in part, 907 F.2d 546 (5th Cir. 1990), cert. denied, 111 S. Ct. 1387 (1991); FSLIC v. Oldenburg, 671 F. Supp. 720, 724 (C.D. Utah 1987).

79 See Continental Casualty Co. v. Allen, 710 F. Supp. 1088, 1097 (N.D. Tex. 1989); McCuen v. International Ins. Co., No. 87-54-D-1, 1988 U.S. Dist. LEXIS 17624, at *9 (S.D. Iowa Sept. 29, 1988), remanded on other grounds, 946 F.2d 1401 (8th Cir. 1991).

${ }^{80}$ Branning, 721 F. Supp. at 1184 (citing 12 U.S.C. § 1729(d) (1988) and Oldenburg, 671 F. Supp. at 723).

${ }^{81}$ Allen, 710 F. Supp. at 1098 (citing Northwestern Mut. Life Ins. Co. v. McCue, 223 U.S. 234 (1911) and Connolly v. Union Sewer Pipe Co., 184 U.S. 540 (1902), overruled on other grounds by Tigner v. Texas, 310 U.S. 141 (1940)). 
explicit statutory or regulatory provision prohibiting the exclusion in D\&O policies, or prohibiting banks and S\&Ls from buying D\&O policies containing the exclusion. ${ }^{82}$ The court then noted that no such provision existed, and thus sustained the exclusion against the government's public policy attack. ${ }^{83}$

\section{The Sixth Circuit Decision}

The Sixth Circuit's May 1990 opinion in FDIC v. Aetna Casualty $\mathcal{E}$ Surety $\mathrm{Co}^{84}$ was the first appellate decision on the enforceability of the regulatory exclusion clause. Aetna involved bankers blanket bonds, a form of insurance policy that insures a financial institution against losses because of theft or employee dishonesty ${ }^{85}$ The bonds at issue contained a termination provision directed specifically at federal banking regulators that, for all practical purposes, was a regulatory exclusion. ${ }^{86}$ The Sixth Circuit rebuffed the FDIC's public policy challenge in two steps. First, the court held that the existence and meaning of a "public policy" are to be gleaned from explicit statutory provisions. The court relied on the Supreme Court's decision in Muschany $v$. United States, ${ }^{87}$ which explained that public policy should be "ascertained by reference to the laws and legal precedents and not from general considerations of supposed public interests. As the term 'public policy' is vague, there must be found definite indications in the law of the sovereignty to justify the invalidation of a contract as contrary to that policy." ${ }^{88}$ Then, the Sixth Circuit determined that there was nothing in federal law that conflicted directly with the existence of the exclusion per se. ${ }^{89}$

The Sixth Circuit's reasoning and holding in Aetna has since been followed by every circuit court ${ }^{90}$ and most district courts ${ }^{91}$

${ }^{82}$ See id. at 1098-99.

83 See id. at 1099.

84903 F.2d 1073 (6th Cir. 1990).

${ }^{85}$ See FDIC REPORT, supra note 14, at 130-44 (providing a general overview and description of bankers blanket bonds).

86 The bond provided: "This bond shall be deemed terminated or canceled as an entirety . . . immediately upon the taking over of the Insured by a receiver or other liquidator or by State or Federal officials." Aetna, 903 F.2d at 1075 (quoting the bond at issue) (emphasis omitted).

87324 U.S. 49 (1945).

${ }^{88} I d$. at 66 (citations omitted).

89 See Aetna, 903 F.2d at 1078.

${ }^{90}$ See Fidelity \& Deposit Co. v. Conner, No. 91-2782, 1992 U.S. App. LEXIS 24337, at *12-*23 (5th Cir. Oct. 1, 1992); FDIC v. American Casualty Co., Nos. 91- 
that have interpreted $\mathrm{D} \& \mathrm{O}$ regulatory exclusion clauses. The substance of the Sixth Circuit's analysis, therefore, warrants further investigation. In Aetna, the Sixth Circuit asserted that no provision of federal law directly settled the question and discussed in some detail 12 U.S.C. $\$ 1821$ (e)(12), the FIRREA provision most relevant to the question. ${ }^{92}$ It provides:

Authority to enforce contracts.

(A) In general.

The conservator or receiver may enforce any contract, other than a director's or officer's liability insurance contract or a depository institution bond, entered into by the depository institution notwithstanding any provision of the contract providing for termination, default, acceleration, or exercise of rights upon, or solely by reason of, insolvency or the appointment of a conservator or receiver.

(B) Certain rights not affected.

No provision of this paragraph may be construed as impairing or affecting any right of the conservator or receiver to enforce or recover under a directors or officers liability insurance contract or depository institution bond under other applicable law..$^{93}$

The Sixth Circuit concluded that the D\&O insurance proviso in this provision explicitly allows regulatory exclusion clauses to be enforced against the FDIC. ${ }^{94}$

6147, 91-6148, 1992 U.S. App. LEXIS 20536, at *6-*14 (10th Cir. Sept. 1, 1992), affg Gary v. American Casualty Co, 753 F. Supp. 1547 (W.D. Okla. 1990); American Casualty Co. v. FDIC, 944 F.2d 455, 460-61 (8th Cir. 1991); see also California Union Ins. Co. v. American Diversified Sav. Bank, 948 F.2d 556, 561-63 (9th Cir. 1991) (involving a bankers bond).

91 See American Casualty Co. v. Kirchner, No. 91-C-0797-C, 1992 U.S. Dist. LEXIS 15879 , at *17 (W.D. Wis. May 22, 1992); FSLIC v. Shelton, 789 F. Supp. 1355, 135859 (M.D. La. 1992); FDIC v. Zaborac, 773 F. Supp. 137, 141 (C.D. Ill. 1991); Powell v. American Casualty Co., 772 F. Supp. 1188, 1190 (W.D. Okla. 1991); St. Paul Fire \& Marine Ins. Co. v. FDIC, 765 F. Supp. 538, 549 (D. Minn. 1991), affd, 968 F.2d 695 (8th Cir. 1992); American Casualty Co. v. Baker, 758 F. Supp. 1340, 1345-46 (C.D. Cal. 1991); Gary v. American Casualty Co, 753 F. Supp. 1547, 1552-53 (W.D. Okla. 1990), affd, Nos. 91-6147, 91-6148, 1992 U.S. App. LEXIS 20536 (10th Cir. Sept. 1, 1992).

Two courts reached opposite conclusions and specifically held the regulatory exclusion to be ambiguous. See FDIC v. Mijalis, No. CIV A 89-1316, 1992 WL 172677, at *14 (W.D. La. June 30, 1992); FSLIC v. Heidrick, 774 F. Supp. 352, 360-61 (D. Md. 1991).

${ }_{92}$ See Aetna, 903 F.2d at $1078-79$.

9312 U.S.C. § 1821(e)(12)(A-B) (Supp. II 1990) (emphasis added).

94 See Aetna, 903 F.2d at 1078-79. 
This conclusion is readily supportable by an analysis of the language and structure of 12 U.S.C. $\$ 1821(\mathrm{e})(12)$. In $\S 1821(\mathrm{e})(12)(\mathrm{A})$, Congress addresses the entire pool of contracts that were entered into by the depository institution and third parties before the institution became insolvent and was placed under the control of a regulatory agency. These contracts may contain clauses that terminate or delimit the third party's obligations upon receivership or conservatorship. Section 1821(e)(12)(B), however, voids these clauses altogether in all contracts that contain them-with the explicit exception of the D\&O insurance contracts (and the bankers bonds). This does not mean that the FDIC may never recover under such contracts, however, because $\S 1821(e)(12)$ purports not to disturb other applicable law that may grant the FDIC the right to recover.

Thus, determining if the regulatory exclusion is ambiguous is left to the discretion of the courts. The courts may choose to invalidate an exclusion as contrary to public policy derived from FIRREA or other statutes, whether federal or state. The Sixth Circuit declined to do the latter, because its interpretation of Muschany necessitated that an explicit provision be found in a statute or regulation, conflicting directly with the regulatory exclusion. If $\S 1821(\mathrm{e})(12)(\mathrm{A})$ did not contain the $\mathrm{D} \& \mathrm{O}$ insurance proviso, it would have been just such an explicit provision. The section is clear, however, and the Sixth Circuit concluded that the exclusion was enforceable. The Sixth Circuit's decision is further supported by analysis of the legislative history of $\S 1821(\mathrm{e})(12)$.

\section{The Legislative History of 12 U.S.C. $§ 1821(e)(12)$}

The issue of public policy and the regulatory exclusion appears to have been on the minds of both D\&O insurers and federal regulators as Congress struggled to finalize the language of FIRREA. Both sides seem to have pressed their cases with Congress. ${ }^{95}$ A contemporaneous report states that initially, the FDIC and FSLIC prevailed on the Senate Banking Committee to settle the conflict by requiring insurers to pay on their policies, regardless of exclusions

${ }^{95}$ See Jerry Knight, A Secret Fight on SELLs: Regulators, Insurers Battle Over Liability Issue in Bailout Bill, WASH. POST, Apr. 30, 1989, at H1 (describing "a secret fight between federal banking regulators and the insurance and banking industries, with hundreds of millions of dollars of the taxpayers' money at stake"); Ken Rankin, Bailout Battle, INS. REV., July 1989, at 9, 10 (describing the lobbying battle between the FDIC and insurers). 
directed at the government suits. ${ }^{96}$ Lobbying by insurers followed, resulting in an uncertain compromise. ${ }^{97}$ Congress essentially took a neutral stand as to the enforceability of regulatory clauses-that is, Congress avoided deciding the matter, leaving its resolution to the courts. Congressional intent was not to affect the development of the law on the subject in either direction. Congressional reports on FIRREA $^{98}$ and the FIRREA debates, ${ }^{99}$ both customary sources of

96 See Rankin, supra note 95, at 9-10.

97 See Knight, supra note 95, at $\mathrm{H7}$ ("The language of the House and Senate amendments is so technical that even lawyers and lobbyists working on the issue disagree over what it means. ... Because the language is so ambiguous, even the lawyers are reluctant to interpret it.").

98 The Senate report states:

[This provision] does not apply to director's and officer's liability insurance contracts or to financial institution bonds. The FSLIC and FDIC have frequently challenged clauses in such contracts or bonds that preclude the deposit insurer from bringing a claim under the contract or bond, contending that the clauses are unenforceable. [This provision] remains neutral regarding such litigation and regarding the FDIC's ability under other provisions of State or Federal law, current or future, to pursue claims on such contracts or bonds. For example, if the law of a particular State declares limitations on the enforceability of director's and officer's liability contracts to be void against public policy, the FDIC could pursue a claim on such a contract under that State's law.

S. REP. No. 19, 101st Cong,, 1st Sess. 315 (1989). A House Committee report similarly states:

[The proposed provision] allows the conservator or receiver to enforce contracts that it deems necessary for the orderly execution of its duties as conservator or receiver, notwithstanding any provision of the contract providing for the termination, default, acceleration, or exercise of rights upon, or by reason of, the institution's insolvency or the appointment of a conservator or receiver, except for directors and officers liability insurance contracts and financial institution bonds. The legislation retains current law for such provisions in directors and officers liability insurance contracts and financial institution bonds.

H.R. REP. No. 54, 101st Cong., 1st Sess., pt. 1, at 381 (1989), reprinted in 1989 U.S.C.C.A.N. 86, 127. Somewhat puzzling is the report's statement that the "majority of courts which have considered the provisions in contracts which provide that coverage terminates upon appointment of a receiver have found such provisions to be against public policy and therefore unenforceable." Id. at 416. The House Report cites Branning v. CNA Ins. Cos., 721 F. Supp. 1180 (W.D. Wash. 1989), and "for a contrary view," cites Continental Casualty Co. v. Allen, 710 F. Supp. 1088 (N.D. Tex. 1989). H.R. REP. No. 54, pt. 1, at 417. At that time, the score was three courts against the exclusion on public policy grounds, and two for it, finding no public policy grounds for invalidation. Thus, a majority existed, but it was hardly well-settled law. It cannot be divined whether the House agrees with this majority or whether the House is merely consoling the FDIC.

The FIRREA Conference Report does not address this matter. See H.R. REP. NO. 209, 101st Cong., 1st Sess. (1989) [hereinafter CONFERENCE REPORT].

${ }^{99}$ Senator Garn (the ranking Republican on the Senate Banking Committee): 
legislative meaning, suggest such congressional intent. That Congress also instructed the FDIC to explain the advantages and disadvantages of possible intervention in a formal study ${ }^{100}$ further demonstrates that they believed the issue had not been decided. The legislative history of 12 U.S.C. $\$ 1821(e)(12)$ lends support to the Sixth Circuit's conclusion that the provisions of FIRREA do not explicitly establish any "public policy" against regulatory exclusions.

\section{Pending Exclusion Litigation and Legislation}

As stated previously, the holding and reasoning of the Sixth Circuit has been widely followed. ${ }^{101}$ The trend in the courts is that the FDIC has successfully litigated most of the insured v. insured clause cases, while losing the majority of the regulatory exclusion cases. Nevertheless, the state of the law in this area remains in flux. Despite its recent setbacks, the FDIC shows no sign of abandoning the issue. Indeed, cases involving the validity of the regulatory exclusion are pending before the U.S. Court of Appeals for the Seventh Circuit, ${ }^{102}$ and the U.S. Court of Appeals for the Fourth Circuit. ${ }^{103}$ A case is also pending before the Supreme Court of Colorado. ${ }^{104}$

Additional litigation is likely to compound further the uncertainty in the law. Another source of uncertainty is the necessary

With respect to directors' and officers' liability insurance contracts, there has been a substantial split in the decisions relating to the validity of regulatory exclusion clauses that prohibit[] a regulator from enforcing rights under the contract.

It is not the intent of the conferees to influence these decisions, or to affect the development of case law or statutory provisions relating to the validity of these clauses and director and officer liability insurance contracts or fidelity or indemnity bonds. The intent of the conferees is to remain neutral on these matters.

135 CoNG. REC. S10,198 (daily ed. Aug. 4, 1989) (statement of Sen. Garn) (citations omitted).

Senator Riegle (Chairman of the Senate Banking Committee): “[T]he managers' amendment excludes director and officer liability insurance and financial institution bond policies from the scope of this provision, and instead directs the FDIC to study this issue and report back to the Congress with legislative recommendations . ..." 135 CONG. REC. S4278 (daily ed. Apr. 19, 1989) (statement of Sen. Riegle).

${ }^{100}$ See CONFERENCE REPORT, supra note 98 , at 454 . The mandated study has been released. See FDIC REPORT, supra note 14.

101 See supra notes 90-91 and accompanying text.

102 See FDIC v. Zaborac, No. 91-3597 (7th Cir. argued Oct. 20, 1992).

${ }^{103}$ See FSLIC v. Heidrick, No. 92-1447 (4th Cir. argued Oct. 27, 1992).

104 FDIC v. Bowen, 824 P.2d 41 (Colo. Ct. App. 1991), cert. granted, FDIC v. American Casualty Co., 1992 Colo. LEXIS 103 (Jan. 27, 1992). 
interaction in these cases between federal courts and state law. While most of the cases are litigated in federal district courts, it is state insurance law that is applied and interpreted. ${ }^{105}$ The unpredictability is compounded by the recent command handed down by the United States Supreme Court in Salve Regina College v. Russell ${ }^{106}$ that circuit courts of appeal must review de novo the district courts' determinations of state law, rather than deferring to the lower courts' determinations. ${ }^{107}$ In addition, litigation on $\mathrm{D} \& \mathrm{O}$ insurance policies in general and the exclusions in particular has already begun in some states ${ }^{108}$ and will likely continue, potentially creating a rich variety of holdings.

If the recent trend in regulatory exclusion litigation continues, the FDIC may go back to Congress to seek redress, as it has attempted in the past. The FDIC recommended in its September 1991 report to Congress that section 1821(e)(12) be amended, and appropriate legislative history supplied, to declare clearly that Congress finds the regulatory exclusion to be a violation of public policy. ${ }^{109}$ After the FDIC's report was released, an amendment to a then-pending banking bill was introduced, proposing to implement the FDIC's request. The amendment was defeated after intense lobbying by insurers. ${ }^{110}$ The FDIC continues to show interest in a legislative solution to its courtroom difficulties. ${ }^{111}$

105 Notions such as contract ambiguity, strict construction of ambiguous clauses against the insurer, and reasonable expectations of the insured are notions of state law, which, while similar across the states, are not necessarily identical.

106111 S. Ct. 1217 (1991).

107 See id. at 1221. The justification for this deference was that district judges presumably have a better ability than the circuits to gauge what state law is or will be after litigating a large number of diversity suits in the states where they sit. See id. at 1221-25. This de novo review will tend to increase the layers of uncertainty. In addition to district court conflict, circuit conflict may yet be introduced as more circuit courts take up the exclusion issue for decision, fulfilling their newly mandated duty to review lower state law determinations. See supra notes 102-03 and accompanying text. Perhaps a circuit court will have to visit the issue multiple times, once for every state within the circuit.

${ }^{108}$ See, e.g., FDIC v. Bowen, 824 P.2d 41, 49-45 (Colo. Ct App. 1991) (sustaining 2 regulatory exclusion), cert. granted, FDIC v. American Casualty Co., 1992 Colo. LEXIS 103 (Jan. 27, 1992).

${ }^{109}$ See FDIC REPORT, supra note 14, at $19-23$ (detailing the FDIC's recommendations).

110 See John F. Olson \& Josiah O. Hatch, Back Into the Game of Backing the Banks, ThE RECORDER, Mar. 18, 1992, at 10; Sherry R. Sontag, Law Puts FDIC's Claims in Peril, NAT'L L.J., Feb. 24, 1992, at 45 (stating that when amendments were introduced, industry lobbyists descended on Congress like a "sea of blue suits"). The amendment was proposed by Rep. Richard H. Baker (R., La.). See id. at 47.

111 For example, see Hearing of the General Oversight and Investigations Subcommittee 
Thus, it is always possible that Congress may act on the FDIC's recommendation to amend FIRREA.

\section{A Policy ANalysis of the Regulatory Exclusion}

In the past year or so, the insurers have gained an edge in regulatory exclusion litigation, making this exclusion the likely preferred tool insurers will use to prevent the FDIC from recovering on the D\&O policies of the S\&L executives. ${ }^{112}$ The FDIC takes the position that the regulatory exclusion is against public policy. ${ }^{113}$ This final Part of the Comment analyzes the regulatory exclusion from a policy standpoint in relation to insurance economics as applied to the S\&L context, taking a somewhat broad look at why exclusions aimed at the FDIC exist. This discussion is directed at the courts that have to decide on the validity of the regulatory exclusion $^{114}$ as well as Congress, which may find it impossible to directly avoid the issue. ${ }^{115}$

of the House Banking Committee, Fed. News Serv., Feb. 20, 1992, available in LEXIS, Nexis Library, Fednew File ("We have vigorously opposed the regulatory exclusion. We believe that it is contrary to public policy because it hinders our efforts. Indeed, it frustrates our congressional mandate to maximize recoveries from those who cause losses .... .") (testimony of the FDIC's General Counsel Alfred Byrne).

112 Because courts have almost universally construed the insured v. insured exclusion against insurers claiming it as a defense to regulatory suits, it will not be pursued further in this Comment as a possible avenue of defense for insurers. To the extent the courts may begin to allow insurers to claim successfully an insured $v$. insured exclusion defense, however, the discussion in Part III is relevant to an analysis of that exclusion as well.

113 See supra text accompanying note 67.

The FDIC has also argued that regulatory exclusions should be invalid by analogy to automatic termination clauses under the Bankruptcy Code. See FDIC REPORT, supra note 14, at 118-126. The Bankruptcy Code invalidates contract clauses that render the contract void upon insolvency or filing for bankruptcy. See 11 U.S.C. $\$ \S 365(\mathrm{e})(1), 541$ (c) (1988). By analogy, the FDIC argues in its report to Congress that " $[t]$ here is no sound policy reason for distinguishing an FDIC receivership from a bankruptcy proceeding in a way that would justify the enforceability of termination on appointment clauses or regulatory exclusions against the FDIC." FDIC REPORT, supra note 14, at 124 . The analysis below shows why the regulatory exclusion should be treated differently as a matter of insurance economics and policy.

114 The courts appear to be aware of the implications of ruling on what might be otherwise seen as a mundane contractual dispute. See, e.g., Continental Casualty Co. v. Allen, 710 F. Supp. 1088, 1098 (N.D. Tex. 1989) ("[T] he Court recognizes the magnitude of its decision due to the apparent widespread use of such [exclusions] and the current banking situation in the Southwest area of the country.").

${ }^{115}$ A clear congressional command in this area would be welcome to prevent continued costly litigation. A substantial portion of the FDIC's recoveries is spent on the FDIC's private litigators. See Legal Division, supra note 21, at 903 (stating that the FDIC's legal expenses in 1991 exceeded \$1 billion). Insurer legal costs are probably 
This section begins with a description of the origin and purpose of the regulatory exclusion clause, then moves to a consideration of basic principles of insurance economics as they apply in the $\mathrm{D} \& \mathrm{O}$ context. The argument in essence is that there are fundamental and compelling reasons why private insurers should not be denied the enforceability of the regulatory exclusion clauses. Without these clauses, insurers are deemed to have insured risks they would have extreme difficulty insuring. The section concludes by briefly setting out what might be termed a fundamental fairness argument against mulcting the pockets of insurers simply because they are deep.

\section{A. The Origin of the Regulatory Exclusion and the Nature of the Excluded Liability}

S\&L managers have not always been subject to the risk of suit with the frequency that is seen today. As will be discussed in greater detail below, until the early 1980s, S\&Ls were subject to very strict governmental regulation and control, allowing only a narrow amount of management discretion. ${ }^{116}$ Indeed, it was possible in a 1983 article on S\&Ls to enumerate and discuss individually every government negligence suit against $S \& L$ executives. ${ }^{117}$ Relaxation of regulatory constraints in the early 1980 s, however, provided S\&L

of similar caliber. In addition, insurers must act with the expectation that there is a possibility that they will have to pay on claims they attempted to exclude. Under the current situation, the FDIC is unable either to predict its expected recoveries to evaluate its investment in litigation or to determine the optimal uses of its limited resources. Likewise, insurers are induced neither to withdraw their coverage altogether (which insurers state they would do if the regulatory exclusion is no longer effectively available), see FDIC REPORT, supra note 14, app. A at 6-11, nor to refrain from passing on the increased cost of possible payouts and legal and related costs to some or all of their insureds. This is why, after the Eighth Circuit sustained a regulatory exclusion in American Casualty Co. v. FDIC, 944 F.2d 455 (8th Cir. 1991), Aetna President Stephen Sills commented: "It interjects a larger element of certainty in the policies we're writing. If we put a regulatory exclusion in a policy . . . we now have a higher degree of certainty that it'll hold up." Appeals Court Rules Against FDIC on Regulatory Exclusion in DËO Policy, 57 Banking Rep. (BNA) No. 13, at 526, 526 (Sept. 30, 1991).

${ }^{116} \mathrm{~S} \&$ Ls were required to invest primarily in home mortgages, a relatively safe, stable, albeit restrictive, asset base. See infra notes 181-83 and accompanying text.

117 See Daniel J. Goldberg, Directors' and Officers' Liability in the Wake of Deregulation, 49 LEGAL BULL. 297, 308-10 \& n.35 (1983) (published by the United States League of Savings Institutions); see also Lyle W. Sparks, A Review of Directors' and Officers' Liability Insurance for Savings Institutions, 51 LEGAL BULL. 101, 120 (1985) ("Instances of threatened claims by regulators are rare except when criminal activity or self-dealing is apparent . . . . Certainly, there is no guarantee that regulators will not sue directors for simple negligence in the future ...."). 
executives with unprecedented investment opportunities. ${ }^{118}$ The result was greater opportunities not only for S\&L profits, but also for losses. The potential for catastrophe was perceptively laid out by one commentator in 1983:

The new deregulated business environment provides savings institutions with more flexibility to pursue business opportunities once unavailable to them. ... Presumably, those business opportunities offer the potential of greater profitability for savings institutions. But along with those new opportunities and that profit potential, directors and officers of savings institutions face new risks. In the new competitive environment, directors, who. previously had to oversee management policies of a highly regulated financial institution, may be exposed to unfamiliar liability risks. Officers, whose previous day-to-day management functions involved the implementation of policies formulated by directors implementing regulatory edict, now have additional duties that call for a close and vigilant analysis of market and competitive forces. Prior to deregulation, it was as if the Bank Board and the FSLIC acted as directors, attended board meetings of savings institutions, and exercised a large measure of control over the business of savings institutions.... If the regulators return to the board room of a savings institution, it will be because they are responding to a savings institution that finds itself in trouble and requires extraordinary relief available only from the Bank Board and the FSLIC. ${ }^{119}$

The worst fears of industry experts have now proven true. Federal regulators have repeatedly returned to $S \& L$ boardrooms to impose enormous liabilities on those D\&Os whose negligence or outright fraud contributed to $S \& L$ failures.

When taking control of an insolvent S\&L, the FDIC faces massive costs. A recent analysis of available data indicated that the government's average cost of closing an insolvent S\&L in 1987 was approximately $35 \%$ of the institution's total assets. ${ }^{120}$ Using this figure, it has been estimated that the average resolution cost per

${ }^{118}$ For a summary of these changes see JAMES R. BARTH \& MICHAEL G. BRADLEY, Thrift Deregulation and Federal Deposit Insurance 5-6 (Federal Home Loan Bank Board Research Paper No. 150, 1988).

119 Goldberg, supra note 117, at 297-98; see also EDWARD J. KANE, THE GATHERING CRISIS IN FEDERAL DEPOSIT INSURANCE 145 (1985) ("Unregulated risks are not only subsidized, they are largely unfunded. The burden of backing up FDIC and FSLIC guarantees falls implicitly on the general taxpayer ....").

${ }^{120}$ See Barth \& Brumbaugh, supra note 16, at 61 . The average resolution cost declined slightly in 1988 to $31 \%$. See id. 
institution is $\$ 180$ million. ${ }^{121}$ This estimate may already be obsolete, however, as recent data indicates even higher closing costs per institution. ${ }^{122}$ Regardless of the exact estimate, it is clear that the government's business of insuring deposits against the possibility of the S\&Ls' insolvency has proven to be an extremely costly undertaking.

To help relieve the enormous burden on the government's deposit insurance fund, federal regulators have pursued those parties who both contributed to S\&L failures and have substantial assets. Because of its limited resources, the FDIC only files claims against targets that have sufficient assets to cover both the FDIC's and the target's defense costs, and still have a reasonable surplus remaining to alleviate a portion of the government's deposit insurance liability. The existence of a D\&O insurance policy is pivotal in that it increases D\&Os' assets substantially, making it more likely that the FDIC will bring suit in the event of an insolvency. ${ }^{123}$ A D\&O insurer, therefore, can expect that when an S\&L becomes insolvent its risk exposure will increase exponentially. ${ }^{124}$ As federal regulators enter the picture, suits against insurers will multiply both in size and frequency. ${ }^{125}$

${ }^{121}$ See id. (estimating the aggregate cost of closing 519 S\&Ls then insolvent to be between $\$ 91$ and $\$ 102$ billion).

122 See $i d$. The most recent congressional action on deposit insurance and depository institution regulation allows the FDIC's Bank Insurance Fund, a much healthier entity than its $\mathbf{S} \& \mathrm{~L}$ counterpart, to borrow about $\$ 70$ billion to replenish itself. See Stephen Labaton, Bank Aid Is Called Insufficient: U.S. Auditor Warns of Future Failure, N.Y. TIMES, Nov. 29, 1991, at D1. But just as the law went into effect, the Comptroller General raised doubts regarding the adequacy of even that amount. See id.

123 A 1989 internal FDIC memo indicated that D\&Os with less than $\$ 5$ million in available assets would typically not be sued. See Justice Should Look to More Civil Than Criminal Cases in Dealing with SELL Fraud, 55 Banking Rep. (BNA) No. 1, at 226, 227 (July 2, 1990).

${ }_{124}$ See Albert B. Crenshaw, Cutting Costs in the Thrift Cleanup: U.S. Seeks to Recover Some Losses from Insurers, but Effort Could Deal Severe Blow to Industry, WASH. POST, Aug. 19, 1990, at H1; Sabin Russell, Thrift Industry Woes May Hurt Insurance Firms, S.F. CHRON., July 25, 1990, at C1.

${ }^{125}$ Insurers, in any case, are typically obligated to pay for their insureds' defense costs. See, e.g., FDIC REPORT, supra note 14, app. B (reproducing the Directors and Officers Insurance and Company Reimbursement Policy from the National Union Fire Insurance Company of Pittsburgh, which provides for coverage of defense costs). Because defense costs are included within the policy limits even if the FDIC recovers nothing in its suit, an insurer will have incurred these costs. This means that, assuming coverage, insurers of S\&L executives expect not only to be liable often, but to pay for defense costs even more frequently as well. Increased litigation with regulators also increases the possibility of insurers being sued by their insureds for 
The regulatory exclusion was created by D\&O insurers in the early 1980 s to offset this risk. ${ }^{126}$ It is unusual in that it excludes all suits brought by particular claimants-FSLIC, FDIC, and other regulatory agencies-rather than a narrow class of claims within all suits. By excluding all regulatory actions from coverage, insurers refused to insure against the enormous liabilities inherent in the specific monstrous event that was most likely to cause regulators to bring suits-an S\&L's insolvency. Regulatory exclusions effectively limited the exposure of insurers to $D \& O$ negligence and fraud up to the point of the S\&L's total collapse, but no further.

There is strong evidence that $\mathrm{D} \& \mathrm{O}$ conduct violating both state and federal law was widespread, ${ }^{127}$ suggesting that the FDIC's suits for fraud and negligence following insolvency will typically be meritorious. D\&O insurers had the foresight, however, to limit their obligation to such suits through the regulatory exclusion. Basic principles of insurance economics demanded the creation of this exclusion, and continue to argue for its enforceability. Those principles can now be explored.

\section{B. The Pooling Problem}

The mere fact that a certain predicted liability is large does not mean that it is uninsurable. Thus, just because D\&O insurers could predict in the early 1980s that insuring the management decisions of insolvent S\&Ls would be very costly does not mean, by itself, that such insurance could not be provided at some price. However, there are additional prerequisites of an insurable risk that make $\mathrm{D} \& \mathrm{O}$ insurance in the context of the S\&L industry a very difficult proposition. This section will explain one such fundamental of insurance-the necessity of risk "pooling." Before explaining how this principle is applicable to the S\&L context, this section will demonstrate pooling's extreme importance by demonstrating its

bad faith denial of coverage. See Lavet, supra note 28, at 212. For a general discussion of bad faith litigation, see WILLIAM M. SHERNOFF ET AL., INSURANCE BAD FAITH LITIGATION (1991).

126 See Sparks, supra note 117, at 120 n.64 ("In view of the approach taken in [recent enforcement litigation], it appears somewhat disingenuous of regulators to profess they do not understand why D\&O carriers are seeking to impose exclusions for suits by regulators.").

${ }_{127}$ See ADAMS, supra note 20, at 22 (asserting that fraud was rampant among D\&Os of failed S\&Ls); MAYER, supra note 20, at 7-8 (asserting that fraudulent accounting practices were used by many S\&L managers). 
utility in analyzing an important insurance-related phenomenon, the insurance crisis of the mid-1980s. ${ }^{128}$

As one commentator has stated, insurance provides "a method for individuals to equalize the amount of money available to them over diverse states of the world-states in which losses occur and those in which there are no losses. ${ }^{\text {129 }}$ Most persons and entities are risk-averse, and therefore wish to prevent the possible severe consequences of an unpredictable loss of low probability. ${ }^{130}$ In a perfect insurance scenario, the risk-averse entity passes on its risk to an insurer-a risk-neutral party-along with a premium. The insurer is risk-neutral when it insures risks of a stochastic or "probabilistic" character. ${ }^{131}$ An insurer "could not sell guarantees of future protection without some estimate of future losses. ${ }^{\text {n132 }}$ The insurer estimates its future obligations within a narrow range by insuring a large pool of insureds with similar expected risks. In creating these pools of insureds, insurers rely on the "Law of Large Numbers," which provides that as the number of insureds with identical risks increases, the total expected loss for the insurer equals the number of insureds multiplied by the expected loss for an individual insured. ${ }^{138}$ Thus, in the ideal case, an insurer could predict its future obligations with certainty. ${ }^{134}$ An insured's premium would then be equal to the cost of the risk insured against multiplied by its probability. ${ }^{135}$

It is important that the size of the expected loss for each insured within a certain pool be reasonably uniform. This uniformity is vital for two reasons. First, it enables the insurer to predict its future liabilities. ${ }^{136}$ Second, uniformity allows the insurer to control the

128 See infra notes $141-47$ and accompanying text.

129 George L. Priest, The Current Insurance Crisis and Modern Tort Law, 96 YALE L.J. 1521, 1539 (1987).

${ }^{130}$ See ROBERT COOTER \& ThOMAS UlEN, LAW AND ECoNomics 63 (1988).

131 See Priest, supra note 129, at 1539-40.

132 ROBERT RIEGEL ET AL., InSURANCE PRINCIPLES AND PRACTICES: PROPERTY AND LIABILITY 17 (6th ed. 1976).

133 See id. at 18-20; Priest, supra note 129, at 1540.

${ }^{134}$ In reality, two factors, moral hazard and adverse selection, cause deviations from the ideal based not on the dissimilarity of insured risks within the pool but on informational problems. Moral hazard is the tendency of an insured to take more risk once insured. Adverse selection is the tendency of those who know they face higher risks to acquire insurance. See COOTER \& ULEN, supra note 130, at 65-67 (further delineating the moral hazard and adverse selection concepts).

135 To this figure, however, must be added a risk premium, plus the insured's share of the insurer's administrative costs and profit, less the insured's share of the insurer's investment income.

${ }^{136}$ See RIEGEL et al., supra note 132, at 20 ("The losses of an insurance company 
problem of adverse selection, or the "tendency of persons with relatively greater exposure to risk to seek insurance protection." ${ }^{137}$ Controlling this phenomenon is crucial to the viability of the pool of insureds, since the size of the pool makes the application of the Law of Large Numbers possible. The premium an insured pays constitutes the insured's share of the risks possessed by all members of her risk pool. If the pool comprises both highrisk and low-risk insureds, the premium required from a low-risk insured would be disproportionate to the risk she brings to the pool, and consequently she will have an incentive to abandon the pool. ${ }^{138}$ "Obviously, as low-risk members drop out, a pool will consist more predominantly of high-risk members, requiring the premium to be raised and placing greater pressure on the remaining low-risk members of the pool. ${ }^{\text {139 }}$ At the limit, the pool may unravel altogether. ${ }^{140}$

The principles of risk pool segregation and disintegration are crucial in analyzing the insurance crisis of the mid-1980s. This crisis occurred when premiums increased and policy limits and overall coverage decreased in Commercial General Liability (CGL) and medical malpractice insurance. ${ }^{141}$ Commentators have debated the causes of these changes and several theories have emerged. ${ }^{142}$

could not be expected to remain uniform if it insured 500,000 insureds for $\$ 1$ each and five insureds for $\$ 100,000$ each. A few losses on the latter would be sufficient to upset all the calculations that could be made.").

${ }_{137}$ Priest, supra note 129, at 1541 .

${ }^{138}$ See id.

139 Id.

${ }^{140}$ See id. at 1542 . The extra cost of risk variance is another consequence of not having narrow risk pools. Two pools may have the same average risk, yet one may have a greater degree of variation and dissimilarity among its individual risks. The latter pool is more costly to insure because more diversification (through investment and reinsurance) is required. Accordingly, the premium increases. See id. Again the increased cost of the premiums enhances the possibility of insurance pool disintegration.

${ }^{141}$ See Richard N. Clarke et al., Sources of the Crisis in Liability Insurance: An Economic Analysis, 5 YALE J. ON REG. 367, 367-68 (1988); Priest, supra note 129, at 1521-22. CGL coverage insures a corporation or other entity against its liability to third parties. Products liability is a prime example of this type of liability.

${ }^{142}$ For a sampling, see Jay Angoff, Insurance Against Competition: How the McCarran-Ferguson Act Raises Prices and Profits in the Property-Casualty Insurance Industry, 5 YALE J. ON REG. 397, 402-06, 415 (1988) (arguing that the insurance industry's antitrust exemption caused the dramatic rate increases and refusals of coverage); Glenn Blackmon \& Richard Zeckhauser, State Tort Reform Legislation: Assessing Our Control of Risks, in TORT LAW AND THE PUBLIC INTEREST: COMPETITION, InNovation, AND Consumer Welfare 272, 292-93 (Peter Schuck ed., 1991) (concluding that increased tort liability affected the insurance crisis and that state tort 
Some have argued that at least one contributor to the crisis was the dynamic change in areas of tort liability law, ${ }^{143}$ including expansion of substantive liability standards, the contraction of available defenses, ${ }^{144}$ and the increase in the variety and magnitude of noneconomic damages. ${ }^{145}$ These changes have caused an increase not only in the amount of the average damage award, but also in the volatility and variability of those awards. This causal relationship is borne out by empirical studies. ${ }^{146}$ These data support the posi-

reforms addressed much of the problem); Clarke et al., supra note 141, at 369 (maintaining that unpredictable changes in tort liability spurred the insurance crisis); Michael J. Trebilcock, The Social Insurance-Deterrence Dilemma of Modern North American Tort Law: A Canadian Perspective on the Liability Insurance Crisis, 24 SAN DIEGo L. REV. 929, 929-33 (1987) (illustrating how attempts to achieve social insurance by the Canadian tort system and its American counterpart debilitated the liability insurance industry); Ralph A. Winter, The Liability Crisis and the Dynamics of Competitive Insurance Markets, 5 YALE J. ON REG. 455, 457 (1988) (rejecting the antitrust exemption theory and adopting the tort rationale).

113 Products liability law is one area of the law that was particularly affected. See W. Kip Viscusi, The Dimensions of the Product Liability Crisis, 20 J. LEgAL STUD. 147, 176-77 (1991) (demonstrating that product liability claims have increased).

144 See Priest, supra note 129, at 1585-36.

145 See id. at $1553-55$.

146 These studies are reviewed in Scott Harrington \& Robert E. Litan, Causes of the Liability Insurance Crisis, 239 ScIENCE 737, 740-41 (1988). See also Blackmon \& Zeckhauser, supra note 142, at 292 (concluding in an empirical study that state law changes in joint and several liability and the imposition of caps on nonpecuniary damages have increased the availability and decreased the cost of insurance).

An analysis of a recent suit by several states against a group of insurance companies, alleging state and federal antitrust law violations, also demonstrates the importance of narrow, uniform risk pooling. See In re Insurance Antitrust Litig., 723 F. Supp. 464 (N.D. Cal. 1989), rev'd, 938 F.2d 919 (9th Cir. 1991). The suits claimed that the insurers had, inter alia, collusively decided to exclude pollution coverage from typical CGL policies. See id. at 469 . Leaving aside the merits of the suit's antitrust claims, several commentators have argued that these "collusive" actions were insurers' attempts at segregating low-risk from high-risk insureds: the "exclusion of pollution coverage from the basic policy serves [the] segregation purpose and reduces differences in risk (reduces risk variance) between members of the pool because it makes all insureds within the pool equivalent with respect to potential pollution claims." George L. Priest, The Antitrust Suits and the Public Understanding of Insurance, 63 TUL. L. REV. 999, 1029 (1989). As in the area of medical malpractice and CGL insurance, pollution claims have given rise to enormous liabilities in recent years. See generally Kenneth S. Abraham, Environmental Liability and the Limits of Insurance, 88 COLUM. L. REV. 942 (1988) (describing the potential burden on CGL insurers); Biel, supra note 45, at 246 (describing the expansion of $D \& O$ environmental liability and the potential burden on D\&O insurers). The pollution exclusion was created by insurers to "prevent[] the prospective costs of pollution from being averaged into the premiums of non-polluters." Priest, supra, at 1029.

Indeed, a Department of the Treasury report in 1982 addressed the feasibility of private insurance for corporate financial responsibility for hazardous waste disposal facilities. It answered the question in the negative, stating that the "major insurability 
tion that increased variability and unpredictability of damage awards (and correspondingly, the liabilities of insurers) has made it exceedingly difficult for insurers to define and maintain narrow, uniform risk pools. Those insureds who perceive their risk to be small, or who find cheaper ways to insure themselves (for example, through self-insurance) exit the pool, leaving those who remain facing higher premiums. The cycle of disintegration will continue as the lower-risk members remaining in the pool are also inclined to exit. ${ }^{147}$

The application of the risk-pool segregation concept to the D\&O liability insurance context is straightforward. If $\mathrm{D \& O}$ insurers could not add a regulatory exclusion to the policies they underwrote, they would have to pool the insured S\&L directors and officers with all other insured D\&Os, spreading the expected liabilities among the total pool membership. In such a case, the monumental liabilities that S\&L directors and officers face when the institution becomes insolvent would shift the average of the risks in the D\&O pool, thereby inducing insurers to raise the premium charged for the entire pool. Low-risk D\&Os would have an incentive to withdraw into cheaper insurance schemes (perhaps self-insurance) where their premiums would not be subsidizing higher-risk insurers. Thus, if insurers did not exclude coverage of D\&Os of insolvent S\&Ls, the enormous and unpredictable liabilities imposed by them would threaten the general D\&O insurance pool with disintegration. The availability of D\&O insurance, itself, is therefore at stake in the exclusion clause litigation. If insurers are not permitted to segregate risks, then insurance for these risks will be in jeopardy. Without the exclusion, the D\&Os of healthy institutions that do not face a serious insolvency risk, and the D\&Os of weaker institutions that, in addition to the risk of insolvency, face other insurable risks, will have difficulty obtaining insurance for those risks. ${ }^{148}$

problem under [the Comprehensive Environmental Response, Compensation, and Liability Act, 42 U.S.C. $\$ \S 9601-9675$ (1988)] has to do with the particular combination of liability and financial responsibility provisions which tend to render the liability exposure of the insurer too uncertain for traditional underwriting practices." DEPARTMENT OF THE TREASURY, HAZARDOUS SUBSTANCE LIABILITY INSURANCE at $v$ (1982).

147 See Priest, supra note 129, at 1564-66; John A. Siliciano, Corporate Behavior and the Social Efficiency of Tort Law, 85 MICH. L. REV. 1820, 1830-33 (1987). For some, insurance becomes so expensive that the insured product or service cannot be priced so that it will be bought by sufficient numbers of consumers to make it profitable, resulting in product or service withdrawals. See id. at 1851 n.108.

${ }^{148}$ See Crenshaw, supra note 124 , at H4. See generally Priest, supra note 129 , at 


\section{The Independent Risk Problem and the Question of Private Insurability}

Assume that insurers could not pool the risks imposed by S\&L directors and officers with the risks imposed by D\&Os in general. Insurers may therefore consider issuing insurance policies to S\&L directors and officers as a separate risk pool, charging them a higher premium in accordance with the higher risk they pose. This section argues that if $\mathrm{D} \& \mathrm{O}$ insurers cannot enforce regulatory exclusions in these policies, insurers will not insure the D\&O risks incident to insolvency at all. The biggest risk S\&L directors and officers impose is the risk of FDIC suits to recover lost deposits as the institutions they run fail. Insuring S\&L directors and officers without a regulatory exclusion, however, would amount to private insurance companies providing deposit insurance. That is, D\&O insurers, without the benefit of the regulatory exclusion, would be forced to insure claims filed both by S\&Ls against their own D\&Os, and also by federal regulators to recover depositors' funds after the institution has gone into receivership. ${ }^{149}$ Privately insuring S\&L deposits would be difficult, if not impossible, because the risks carried by the pool of insureds-here, the S\&L directors and officers-would be apt to occur together. This would violate a fundamental principle of insurance economics-that insured risks be independent. This section will explain the independence principle and its importance, best illustrated by the failure of three private deposit insurance schemes in Rhode Island, Ohio, and Maryland. The section concludes that if forced to cover claims incident to insolvency, $D \& O$ insurers stand to suffer the same fate as these private deposit insurance companies.

A viable pool of insureds requires not only that the risks insured against be reasonably uniform but also that they be independent. ${ }^{150}$ Independence mandates that the occurrence of one loss

1571-76 (discussing the effect of increased variance on provider risk pools).

149 This assertion is not entirely true, of course, because $D \& O$ insurers would not have to pay for insolvencies resulting from market conditions or other factors not related to the competence or prudence of the D\&Os. Still, the FDIC has been vigorously pursuing cases where recovery may be possible. Litigation is likely to increase if courts continue to hold that the standard to which D\&Os should be held is one of simple, not gross, negligence. The majority of courts that considered the question found that simple negligence was the proper standard. See Cindy A. Schipani, Should Bank Directors Fear FIRREA: The FDIC's Enforcement of the Financial Institution Reform, Recovery, and Enforcement Act, 17 J. CORP. L. (forthcoming 1993) (manuscript at 23-31, 53, on file with author).

150 See JAMES R. BARTH ET AL., REFORMING FEDERAL DEPOSIT INSURANCE: WHAT 
insured against must not affect the probability of the occurrence of a second loss. ${ }^{151}$ An insurer cannot insure events apt to occur in high numbers at the same time, rather than being spread out over time. Only if risks are independent can an insurer "accumulate small premiums from each insured and still have funds sufficient in any period to pay those losses that actually occur."152 A possibility that there may be a catastrophic loss across the risk pool makes insurance of the pool itself impossible. ${ }^{153}$

Deposit insurance, or by analogy, $\mathrm{D} \& \mathrm{O}$ insurance for claims incident to insolvency, does not meet this criterion. ${ }^{154}$ Recent experience with private deposit insurance in Rhode Island, Ohio, and Maryland is illustrative of the difficulty of privately insuring against S\&L insolvencies. In November 1990, a small, two-branch bank in Providence, Rhode Island, failed. The bank's deposits were not insured by the government, but by a private insurance company, The Rhode Island Share and Deposit Indemnity Fund (RISDIF). RISDIF exhausted much of its reserves in reimbursing depositors for their lost money. ${ }^{155}$ Because of impending trouble at other institutions insured by RISDIF, RISDIF requested the state to take over and control its operations, signaling the end of its business. ${ }^{156}$ The state closed the institutions insured by RISDIF as it attempted to generate the funds necessary to back up the deposits held in these institutions. ${ }^{157}$ These deposits remained frozen until a $\$ 150$ million bailout bond issue produced sufficient funds to refund depositors most of their money. ${ }^{158}$

The Rhode Island events were similar to earlier S\&L failures in other states. In March of 1985, after a securities-trading firm

Can Be learned from Private Insurance Practices? 13 (1989); Emmett J. VAUGHAN, FUNDAMENTALS OF RISK AND INSURANCE 29 (5th ed. 1989); Priest, supra note 129 , at 1540 .

${ }^{151}$ See Priest, supra note 129, at 1540 n.98.

152 Id. at 1540 .

153 See BARTH ET AL., supra note 150, at $13 \mathrm{n} .13$ ("The risk of being unemployed . is another risk that does not satisfy [the independence] characteristic. The government, therefore, provides unemployment insurance."); Priest, supra note 129, at 1540 ("Thus, losses from nuclear war are uninsurable.").

154 See BARTH ET AL., supra note 150, at 12-13.

155 See Keith Bradsher, 45 Credit Unions and Banks Shut by Rhode Island, N.Y. Times, Jan. 2, 1991, at A1, D2.

156 See id.

157 See id. at A1. According to then FDIC Chairman L. William Seidman, RISDIF's failure was "one of the largest we've seen in several decades." Id. at D2 (quoting Seidman).

${ }^{158}$ See Rhode Island Gets Bank Bailout Law, N.Y. TmMEs, Feb. 10, 1991, § 1, at 32. 
collapsed, a state-chartered Ohio S\&L stood to lose millions of dollars, placing the security of its deposits at grave risk. ${ }^{159}$ The threat of this collapse precipitated a panic among depositors, and a run on both healthy and unhealthy $S \& L s,{ }^{160}$ putting tremendous pressures on the Ohio Deposit Guarantee Fund, a non-profit private deposit insurance company. ${ }^{161}$ To end the run, the Ohio Governor ordered all seventy-one privately insured institutions closed, a decision that left many depositors without cash until the end of the crisis. ${ }^{162}$ The state authorized an emergency deposit insurance fund while the institutions at risk began purchasing federal deposit insurance. ${ }^{163}$

About eight weeks after the Ohio failures, Maryland's S\&Ls found themselves wallowing in the same murky waters. A change in the top management of the state's second largest S\&L and press reports that the institution had grown too rapidly ${ }^{164}$ caused a run on that institution and others insured by the private Maryland Savings Share Insurance Corporation (MSHIC). ${ }^{165}$ Unable to meet the demands of insured depositors, MSHIC was on the verge of collapse. Maryland's Governor, invoking his emergency powers, ordered all 102 institutions privately insured by MSHIC to limit withdrawals to $\$ 1000$ per month. ${ }^{166}$ The Maryland state legislature responded by granting the Governor further S\&LL regulatory powers, and by requiring that all qualifying institutions apply for federal deposit insurance. ${ }^{167}$ For those S\&Ls too small to qualify for federal insurance, a state insurance fund was created. ${ }^{168}$

159 See Kenneth N. Gilpin \& Todd S. Purdum, Ohio Legislator Fights to Protect Deposits, N.Y. Tumes, Mar. 15, 1985, at D2.

${ }^{160}$ See Gary Klott, 71 Ohio Savings Institutions Shut for 3 Days in Effort to Stem Run, N.Y. TIMES, Mar. 16, 1985, at 1 ("At several institutions in the Cincinnati area, long lines of depositors, many of whom had camped out overnight, had already formed outside the banks [before state-ordered temporary shutdowns].").

161 See Gilpin \& Purdum, supra note 159, at D2.

162 See Klott, supra note 160 , at 3.

163 See id.

164 See Eric N. Berg, Maryland Enacts Laws on Thrifl Units' Crisis, N.Y. TIMES, May 18,1985 , at 35 .

165 See Eric N. Berg, Maryland Limits All Withdrawals from Thrifl Units, N.Y. TIMES, May 15, 1985, at A1.

166 See id.

167 See Berg, supra note 164, at 35. The week before the action of the state legislature, the Federal Reserve Bank already had tripled the amount of money lent to the Maryland S\&Ls. See id. at 38.

168 See id. Interestingly, this state agency, the Maryland Deposit Insurance Fund, ended up facing massive losses similar to the FSLIC's and the FDIC's losses on a national level, and also became involved in regulatory exclusion litigation with D\&O 
The demise of private deposit insurance systems in these three states dramatically illustrates the impossibility of privately insuring risks that are not independent. Insurers have great incentive to avoid or minimize their exposure to risks that are not independent enough to avert multiple catastrophic claims on the insurance fund. ${ }^{169}$ The regulatory exclusion is a legitimate tool used by $\mathrm{D} \& \mathrm{O}$ insurers to minimize exposure to such risks.

\section{The Moral Hazard Problem and the Need for Governmental Regulation}

This section explains why, compared to the federal government, private insurers are less capable of insuring claims incident to insolvency. As will be demonstrated, only the government can prevent the excessive risk-taking to the extent necessary for this D\&O insurance. Such insurance is viable only if certain measures are taken to prevent excessive risk-taking-measures that only the federal government can effectively take.

insurers. See Finci v. American Casualty Co., 593 A.2d 1069, 1076-79 (Md. 1991) (holding that regulatory exclusions are not invalid on public policy grounds), rev'g, 579 A.2d 281 (Md. Ct. Spec. App. 1990).

Privately insured institutions in other states were also moving toward purchasing federal insurance. By mid-1985, all of North Carolina's institutions had applied for federal coverage; Massachusetts S\&Ls followed closely behind. See Nathaniel C. Nash, Washington Watch: Private Deposit Insurance Bills, N.Y. TIMES, May 20, 1985, at D2.

Indeed, it appears that RISDIF, the Rhode Island private insurance scheme, was the last private entity to insure any depository institution other than credit unions. See Michael Quint, About 10\% of Credit Unions Are Privately Insured, N.Y. TIMES, Jan. 3, 1991, at D4 (listing the remaining private deposit insurers that insure only credit unions). Credit unions are tightly regulated creatures with little leeway for risktaking. Nevertheless, even among them, there was a palpable shift from private to federal insurance, a shift that was required by legislatures in some states. See Michael Quint, Move to U.S. Insurance Is Seen at Credit Unions, N.Y. TIMES, May 20, 1991, at D4 (stating that approximately 500 credit unions were expected to move from private to federal insurance by September of 1991).

${ }^{169}$ Accordingly, even when the government undertakes the task of insuring possibly correlated risks, it also has incentive to control or limit its exposure to catastrophic losses. For example, legislation was recently introduced in Congress to reform the national flood insurance program. See Gregory Spears, Flood-Insurance Plan Worries Coastal Owners, PHILA. INQUIRER, Dec. 2, 1991, at A2. "[T] here is a potential for immense losses as natural forces such as wind and water move barrier islands. Insuring homes built on shifting sands is like issuing life insurance policies to 80-year-olds ...." Id. (paraphrasing a national flood insurance official). The proposed legislation would forbid certain potentially risky construction and pressure some insured homeowners to move. See id.

Unfortunately, the federal government failed to minimize its losses in deposit insurance. See infra notes $\mathbf{1 8 4 - 8 8}$ and accompanying text. 
Deposit insurance inherently creates incentives for S\&LL executives to take excessive risks, whether the insurance is provided by federal deposit insurers or by private $\mathrm{D} \& \mathrm{O}$ insurers covering liability suits following insolvency. When a person acquires insurance of any type, she will have less of an incentive to prevent a covered loss by taking extra care, spending more on loss avoidance, or avoiding activities or situations in which the loss may materialize. The incentive for risky behavior created by insurance is commonly referred to as the moral hazard phenomenon. ${ }^{170}$ In the case of deposit insurance, this phenomenon manifests itself on two levels. First, without insurance, a customer will be motivated to deposit her money in a strong bank or S\&L-one that carefully manages its investment portfolio and diversifies its investment risks. Accordingly, such a depositor will theoretically be induced to learn more about the management practices of the institutions vying to open an account for her. Deposit insurance eliminates this incentive. ${ }^{171}$ The security of her deposits assured regardless of the decisions of an institution's executives, a customer will not choose a bank or S\&L based on its investment track record. Second, the moral hazard phenomenon is more acutely present because deposit insurance acts as third-party insurance for S\&cL executives against the claims of depositors. "[D]eposit insurance is rather unique in that the parties whose risk-taking needs to be curtailed (owners and managers of depository institutions) differ from those that are insured (depositors). ${ }^{n 172}$ These executives are therefore inclined

170 See supra note 134; Priest, supra note 129, at 1547. One can distinguish between ex ante and ex post moral hazard. The former is "the reduction in precautions taken by the insured to prevent the loss, because of the existence of insurance." Id. The latter is the "increase in claims against the insurance policy beyond the services the claimant would purchase if not insured." Id.

171 See GEORGE J. BENSTON ET AL., BLUEPRINT FOR RESTRUCTURING AMERICA'S FINANCIAL INSTITUTIONS: REPORT OF A TASK FORCE 2-3 (1989) (arguing that because insured depositors look to the insuring agency for protection rather than to the depository institution, weakly capitalized institutions taking large risks can bid for insured deposits on near equal footing with strongly capitalized institutions taking smaller risks); R. DAN BRUMBAUGH,JR., THRIFTS UNDER SIEGE: RESTORING ORDER TO AMERICAN BANRING 35, 57 n.5 (1988); ROGER C. KORMENDI ET AL., CRISIS RESOLUTION IN THE THRIFT INDUSTRY: A MID-AMERICA INSTITUTE REPORT 13-15 (1989); James R. Barth et al., Moral Hazard and the Thrift Crisis: An Empirical Analysis, 44 CONSUMER FIN. L.Q. REP. 22, 29 (1990). The argument made by some commentators is that even if only a few depositors (or deposits) are uninsured, they may exert enough pressure on $S \& L$ management that overly risky investments will be avoided. See Macey \& Miller, supra note 14, at 1193-99.

172 BARTH ET AL., supra note 150 , at 1 . 
to invest the deposits in potentially very profitable, but very risky, ventures. This is particularly true when the institution is nearing insolvency. ${ }^{178}$

To correct for the moral hazard problem, an insurer could impose certain restrictions on S\&Ls and their D\&Os. ${ }^{174}$ Private and federal insurers would have very different ways of enforcing these requirements, however. A private insurer can do no more than threaten to cancel or deny coverage if the executives of a particular S\&L take undue investment risks. But upon cancellation (or the threat thereof), the true insureds, the depositors, will still be exposed to the risk of deposit loss; heavy withdrawals followed by runs will ensue. ${ }^{175}$ In contrast, a federal agency can be given the rulemaking and sanction powers necessary to deter excessive risktaking on the part of the D\&Os without depriving the depositors of deposit protection.

The powers of federal regulators and insurers exceed those of private insurers in certain important respects. Federal regulators possess the power of early closure, the authority to close a weak S\&L even before it is totally insolvent in order to prevent a major loss. ${ }^{176}$ The regulators' capital requirements can serve to compel

173 See BENSTON ET AL., supra note 171, at 3; KORMENDI ET AL., supra note 171, at 13-15. When facing impending insolvency, executives attempt to recover what was lost, and to do so quickly. This tendency has been empirically demonstrated in a recent study. See Barth et al., supra note 171, at 29-34.

174 For example, the insurer could mandate investment restrictions that require the avoidance of specify risky investments, or net worth restrictions that require the maintenance of a minimum net worth.

${ }^{175}$ See supra notes $155-68$ and accompanying text for descriptions of recent examples of how depositors may react to doubtful (not even the absence of) deposit insurance.

Some have argued that the threat of cancellation of coverage or increases in premiums may induce the depositors to monitor the bank or S\&L's management and provide "market discipline." See Macey \& Miller, supra note 14, at 1193-1202 (discussing the theoretical underpinnings of and empirical evidence for market discipline); Jonathan R. Macey \& Elizabeth H. Garrett, Market Discipline by Depositors: A Summary of the Theoretical and Empirical Arguments, 5 YALE J. ON REG. 215, 216 (1988) (same). There is no consensus on this point by any means and the debate, both on theoretical and empirical grounds, has been strong and continues to rage on. For critiques of the market discipline theory see Helen A. Garten, What Price Bank Failure?, 50 OHI ST. L.J. 1159, 1162 (1989); Helen A. Garten, Still Banking on the Market: A Comment on the Failure of Market Discipline, 5 YALE J. ON REG. 241, 242-43 (1988).

176 See BARTH ET AL., supra note 150, at 29; George G. Kaufman, Framework for the Future: Resurrecting and Legitimizing the Thrifi Industry, in THE FUTURE OF THE THRIFT INDUSTRY 191, 198-205 (1989) (Proceedings of the Fourteenth Annual Conference of the Federal Home Loan Bank of San Francisco, Dec. 8-9, 1988). It is argued that the 
S\&L directors and officers to maintain liquid a specific amount of money in reserve to refund depositors should the S\&L suffer major losses. ${ }^{177}$ In addition, federal regulators have the power to bar a negligent $\mathrm{D} \& O$ from serving in any federally insured institution, a power unavailable to private insurers. ${ }^{178}$ Enforcing these and other requirements demands continual monitoring and record examination. Thus, even if a private company was in principle willing to insure deposits, it would not do so because it would not have the means available to a governmental agency to force the kind of disclosure the above-described measures require.

\section{E. Regulatory Failure and the Search for a Deep Pocket}

In analyzing the litigation between the FDIC and the D\&O insurers, a general fairness argument that the federal government not be allowed to shift the S\&L industry's losses to private insurance companies is attractive. ${ }^{179}$ Many commentators have argued that S\&L deregulation in the early 1980 s was ill-advised in that it increased the incentives of S\&L directors and officers to take excessive risks. ${ }^{180}$ Even if deregulation were, on the whole, desirable, the federal government still did not install the strict monitoring and examination apparatus necessary to insure regulatory intervention before catastrophe struck the newly unencumbered industry.

The combined deregulatory legislation of $1980^{181}$ and $1982^{182}$ ended a half century of strict governmental control of

costs to the federal government of the S\&L crisis have increased because S\&Ls tend to be insolvent for a long period of time before closure, see supra note 16, during which the S\&Ls sink deeper and deeper into debt. See Barth et al., supra 171, at 30 .

177 See BENSTON ET AL., supra note 171, at 9-19; Barth et al., supra note 171, at 30.

178 See, e.g., Executive Barred from Banking After Failed Attempt to Acquire Illinois Bank, 52 Banking Rep. (BNA) No. 10, at 596, 596 (Mar. 6, 1989) (reporting the removal of a person from the banking business because of his "demonstrated dishonesty and disregard for bank safety") (quoting the FDIC).

179 See FDIC REPORT, supra note 14, app. A at 11 (quoting a comment by CNA Insurance Companies submitted to the FDIC, stating that "regulators . . . sought to reimburse themselves as insurers for losses resulting in some measurable part from faulty or inadequate regulation. In our view, the government should not look to private industry to make it whole from the sins of its own excesses."); Lavet, supra note 28 , at 211 .

${ }^{180}$ See infra notes $184-88$ and accompanying text.

181 See Depository Institutions Deregulation and Monetary Control Act of 1980 (DIDMCA), Pub. L. No. 96-221, 94 Stat. 132 (1980) (codified as amended in scattered sections of 12 U.S.C. and 15 U.S.C.).

182 See Garn-St. Germain Depository Institutions Act of 1982, Pub. L. No. 97-320, 
S\&L actions by abolishing the limits on interest rates that S\&Ls could provide depositors, and expanding both the types of loans they could offer and the types of assets in which they could invest. These laws were passed to increase the S\&L industry's ability to remain competitive with commercial banks and money market funds. ${ }^{183}$ Unfortunately, deregulation also created a considerable moral hazard for D\&Os that needed to be offset by vigilant federal supervision. ${ }^{184}$ This did not occur, however. In fact, the funds available for federal bank examinations declined. ${ }^{185}$ The S\&L industry vigorously lobbied Congress to delay recapitalization of the federal deposit insurance fund (thereby delaying further closures of marginal S\&Ls) and to keep regulators and examiners at bay. ${ }^{186}$

96 Stat. 1469 (1982) (codified as amended at scattered sections of 12 U.S.C.). For a summary of both DIDMCA and Garn-St. Germain see BARTH \& BRADLEY, supra note 118 , at 5-6. For a summary of concurrent regulatory developments, see id. at 9-12. ${ }^{183}$ See Azar, supra note 1, at 152-53.

184 See Barth et al., supra note 171, at 29; Edwin J. Gray, The Role of Regulation in the Thrift Industry, 6 ANN. REV. BANKING L. 235, $241-45$ (1987); Robert V. Shumway, The Compatibility of Deregulation and Increased Supervision, 6 ANN. REV. BANRING L. 247 passim (1987); William Taylor, Deregulation and Prudent Supervision, 6 ANN. REv. BANKING L. 253, 255 (1987). Mr. Gray was then FHLBB Chairman; Mr. Shumway was then Director of the Division of Bank Supervision at the FDIC; the late Mr. Taylor was then Director of the Division of Banking Supervision and Regulation at the Federal Reserve (and, most recently, FDIC Chairman).

${ }^{185}$ As three former economists for the Federal Home Loan Bank Board asserted:

While the need for examination and supervision is increased in an increasingly competitive and deregulated environment, [the data] show that the examination staff and budget failed to keep pace with the growth in total industry assets and the entry of thrifts into new activities. Highly trained and well-paid examiners are not made obsolete by deregulation, but rather become indispensable as competition heats up and capital is eroded away. .... In sum, without adequate safeguards, federal and state deregulation is a cause of the current thrift crisis.

Barth et al., supra note 171, at 28-29.

Similarly, then-FHLBB Chairman Gray bitterly complained in a 1986 speech:

In [1984], [the Office of Management and Budget] simply refused our pleas for more examiners .... It was difficult, if not impossible, for the Bank Board to examine and supervise a fast growing industry with many institutions knee-deep in problems and others on the verge of failure.

... [W]e had 750 field examiners nationwide, whose average yearly salary was 25 thousand dollars. The examiner turnover rate was as high as 28 percent per annum. Entry level salaries were limited to 14 thousand dollars a year. Yet this field force was called upon to examine an industry whose assets exceeded one trillion dollars.

Gray, supra note 184, at 243.

${ }^{186}$ As one commentator remarked: "First, the industry supported regulatory accounting standards that masked its serious capital problems during the most critical phase of the industry's demise. Second, the lobbying campaign led to a dramatic 
Indeed, several members of Congress may have acted improperly in yielding to lobbyists' pressure. ${ }^{187}$ In the wake of the crisis, commentators have placed responsibility for the industry's failure largely on the catastrophic mixture of federal deregulation and lax regulatory supervision. ${ }^{188}$

underfunding of the federal government's initial effort to address the S\&L crisis." Grundfest, supra note 20, at 29; see also ADAMS, supra note 20 passim (recounting example after example of questionable S\&L industry influence on Congress); MAYER, supra note 20 passim (same); Edwin J. Gray, Warnings Ignored: The Politics of the Crisis, 2 STAN. L \& POL. REV. 138, 138-39, 142-44 (1990) (describing congressional delay of the S\&L rescue and intervention in the regulatory process); Thomas Romer \& Barry R. Weingast, Congress: The Genesis of the Thrift Crisis, 2 STAN. L \& POL. REV. 37, 39-44 (1990) (same); Michael Waldman, The SE'L Collapse: The Cost of a Congress for Sale, 2 STAN. L \& POL. REV. 47 passim (1990) (same).

187 Five senators allegedly received improper campaign contributions from Charles H. Keating, Jr., head of Lincoln Savings and Loan Association, a large California S\&L. See David E. Rosenbaum, A Financial Disaster With Many Culprits, N.Y. TIMES, June 6, 1990 , at A1, D4. The Senate Ethics Committee "strongly and severely' reprimanded [one of them] for acts it called "improper and repugnant," and "admonished" the others "for giving the appearance of impropriety." An Apology, of Sorts, from a Senator, N.Y. TrMEs, Nov. 24, 1991, § 4, at 7. "Representatives Jim Wright of Texas, the Speaker of the House, and Tony Coelho of California, the majority whip, were forced from office ... in part because of questionable dealings with savings officials." Rosenbaum, supra, at D4. Former House Banking Committee Chairman Fernand St. Germain "lost his seat in 1988 largely because of gifts from [banking] industry lobbyists." Id.

Congress did not have a monopoly on this kind of conduct. M. Danny Wall, Chairman of the FHLBB between 1987 and 1989 (and briefly of the new OTS), resigned under a cloud. See Nathaniel C. Nash, Top Savings Regulator Resigns and Strikes Back at His Critics, N.Y. TIMES, Dec. 5, 1989, at A1. Questions were raised about Mr. Wall's involvement with Lincoln Savings and Loan, whose resolution is the costliest ever. See id. "To this day, few people say they understand why Mr. Wall repeatedly came out with the low estimate. Mr. Wall has repeatedly denied an assertion by some critics that in a Presidential election year he felt it was his responsibility to keep the savings crisis quiet." Id. at B19. Even the president's son, Neil Bush, was found to have violated conflict-of-interest regulations as director of a Denver S\&L, whose failure will cost the federal government more than $\$ 1$ billion. See Douglas Frantz, Neil Bush Broke Conflict Rules, Official Decides, L.A. TIMEs, Dec. 19, 1990 , at D1.

188 See supra notes 184-86. One aspect of this laxity is special accounting rules. In United States v. Centennial Sav. Bank FSB, 111 S. Ct. 1512 (1991), and Cottage Sav. Ass'n v. Commissioner, 111 S. Ct. 1503 (1991), both tax cases, the Supreme Court held that the regulatory accounting rules adopted in the early 1980 s to hide S\&L losses were immaterial as to questions of tax liability or credit.

It should be noted that as a matter of law the federal government is not liable under the Federal Tort Claims Act for any regulatory laxity, due to its discretionary function exception. See Federal Tort Claims Act, 29 U.S.C. $\$ 2680$ (a) (1988); see also United States v. Gaubert, 111 S. Ct. 1267, 1275 (1991) (holding that the Federal Tort Claims Act's discretionary function exception reached decisions made by federal regulators' supervision of S\&Ls day-to-day operations). 
Thus, excluding regulatory suits is not only justified as a matter of basic insurance economics, but also as a matter of fairness. Private insurers prudently attempted to avoid exposure to failurerelated risks for all the reasons explained earlier in this Part. They should not be required now to pay for the losses. ${ }^{189}$ The federal government undertook to insure these losses; despite the political costs, it should honor its obligations.

\section{CONCLUSION}

When Congress deregulated the S\&Ls in the early 1980 s, D\&Os of S\&Ls were given significant discretion in making investment decisions. Prior to deregulation, the risk of government lawsuits against D\&Os following an S\&L's failure was minimal. Deregulation enlarged this risk dramatically. $\mathrm{D} \& O$ insurers responded to this increased liability by attempting to enforce existing, or create new, policy clauses that excluded suits brought by federal regulators incident to institutions' insolvency. In the resulting litigation between insurers and federal regulators, the FDIC has managed to win most of the cases dealing with the insured v. insured clause, but not those dealing with the regulatory exclusion.

This Comment has argued that the insurers' desire to avoid insuring D\&Os of insolvent S\&Ls is well-founded in basic insurance principles. Privately insuring such risks is nearly impossible as the risks are neither reasonably uniform nor sufficiently independent. Furthermore, viable D\&O insurance in the S\&L context requires monitoring and control of industry activity, a requirement that is considerably easier for governmental regulators to accomplish than

189 One must sometimes make an affirmative effort to resist the impulsive penalizing of deep pocket entities simply because they are such. Consider the following from The Oxford Book of Legal Anecdotes:

We have a judge in Boston who is indeed brilliant, but a character. A jury case was being tried before him, a personal injury case, and the jury sent a note to him with a question asking if, even if there was not any liability, they could still give the plaintiff some money.

[The Judge] sent for the jury. He said to them, "I have your written question, and I assume from the question that you have found there is no liability."

The foreman said, "That is so, Your Honour." He said, "All right, sign this slip then."

After they had signed the slip, which directed a verdict for the defendant, he said, "I will now answer your question. You may retire to the jury room and pass round the hat."

THE OXFORD BOOK OF LEGAL ANECDOTES 110 (Michael Gilbert ed., 1986). 
for a private insurer. Private insurers did not willingly insure S\&L executives in an era of deregulation, and they should not now be found to have done so. Excluding insolvency-related claims from coverage is not only supported by principles of insurance economics, but is also desirable. The regulatory exclusion enhances the availability of insurance for insurable risks by clearly segregating them from uninsurable ones. Without an enforceable regulatory exclusion, insurers would not be willing to insure any S\&L directors and officers. Neither Congress nor the courts should now accept the FDIC's invitation to forge an opposite course. ${ }^{190}$

${ }^{190}$ Freeing private insurers of this liability does not completely end the inquiry. If the federal government cannot turn to private insurance to guard against the loss of deposits upon S\&L failure, it faces a choice. One option is for the government to exit the deposit insurance business altogether. See England, supra note 7, at 254-55. The alternative is for the government to continue to insure deposits as it has done in the past. Not only is the latter alternative the more likely course politically, but federal deposit insurance can be seen as a public good in that it protects the small depositor and maintains public confidence in the financial system as a whole. Indeed, the state and federal governments frequently function as insurers. See generally WARREN FREEDMAN, RICHARDS ON THE LAW OF INSURANCE $\$ \S 14: 1-14: 20$ (6th ed. 1990 \& Supp. 1991) (providing multiple examples of the government as insurer).

Unlike private insurer reserves, the government can provide an unconditional, limitless guarantee. If depositors realized that their money is absolutely safe, federal funds would rarely be needed because there would be no panic or massive withdrawal of deposits. See Douglas W. Diamond \& Philip H. Dybvig, Bank Runs, Deposit Insurance, and Liquidity, $91 \mathrm{~J}$. POL. ECON. 401, 413-16 (1983) (employing a theoretical analysis to demonstrate that bank runs will not occur with government deposit insurance); William M. Isaac, The Role of Deposit Insurance in the Emerging Financial Services Industry, 1 YALE J. ON REG. 195, 201 (1984) (then-FDIC Chairman arguing that public confidence in the banking system is a major goal of governmental deposit insurance). Offering a deposit guarantee, however, imposes on the government a corresponding duty. If the government wishes to insure $\mathrm{S} \& \mathrm{~L}$ deposits unconditionally, it is obligated to regulate and monitor the S\&Ls' D\&Os' actions closely, as it has done since the passage of FIRREA. Governmental regulations and guidelines, as well as supervision and monitoring, should function as safe harbors to complying D\&Os, offering protection from liability incident to insolvency. Accordingly, a division of labor materializes. Private insurers continue to cover insurable D\&O risks, while the government covers the insolvency risk and enforces appropriate regulations. 
